\title{
Lapita all over: Land-use on the Willaumez Peninsula, Papua New Guinea
}

\author{
Jim Specht and Robin Torrence
}

\author{
Anthropology Unit \\ Australian Museum \\ Sydney NSW 2010, Australia \\ jspecht@bigpond.com; robint@austmus.gov.au
}

\section{Introduction}

The remarkable achievements of the first colonisers of the Remote Pacific have long captured the interest of archaeologists and the wider public alike. Perhaps for this reason the character of the archaeological evidence in that particular region has been implicitly used as the exemplar for all areas where Lapita pottery is found (cf. Green 1992:16). For example, one of the long held tenets of Lapita archaeology is that settlement was mainly restricted to small, offshore islands or, where it occurred on larger islands, it was almost exclusively limited to the coastal margins and to beaches in particular (e.g., Frimigacci 1980; Kirch 1997:162-167; Lepofsky 1988; Spriggs 1997:88, 122). Recently, this view was challenged by a study of cultural landscapes on Garua Island, Papua New Guinea in the western area of Lapita pottery distribution (Figure 1), where intentional searching of zones usually overlooked by Pacific archaeologists has revealed an intriguing shift in landuse patterns during the dentate-stamped phase of the Lapita ceramic series (Torrence 2002a; Torrence and Stevenson 2000). The earliest sites with dentate-stamping were located on beaches or in the inter-tidal zone of Garua and adjacent small islands, but from about 3050-2750 cal. BP the focus of activity shifted to elevated inland locations, possibly to take advantage of defensive capabilities provided by steep-sided hills and ridges (Torrence and Stevenson 2000).

The Garua Island study raises important questions about the homogeneity of behaviour across the huge expanse where Lapita pottery has been found, particularly in terms of the use of inland hills and forests. A recent gazetteer of 184 Lapita sites with dentate-stamped pottery (Anderson et al. 2001: Table 1) highlights the contrast between the islands of the Bismarck Archipelago that had been settled 


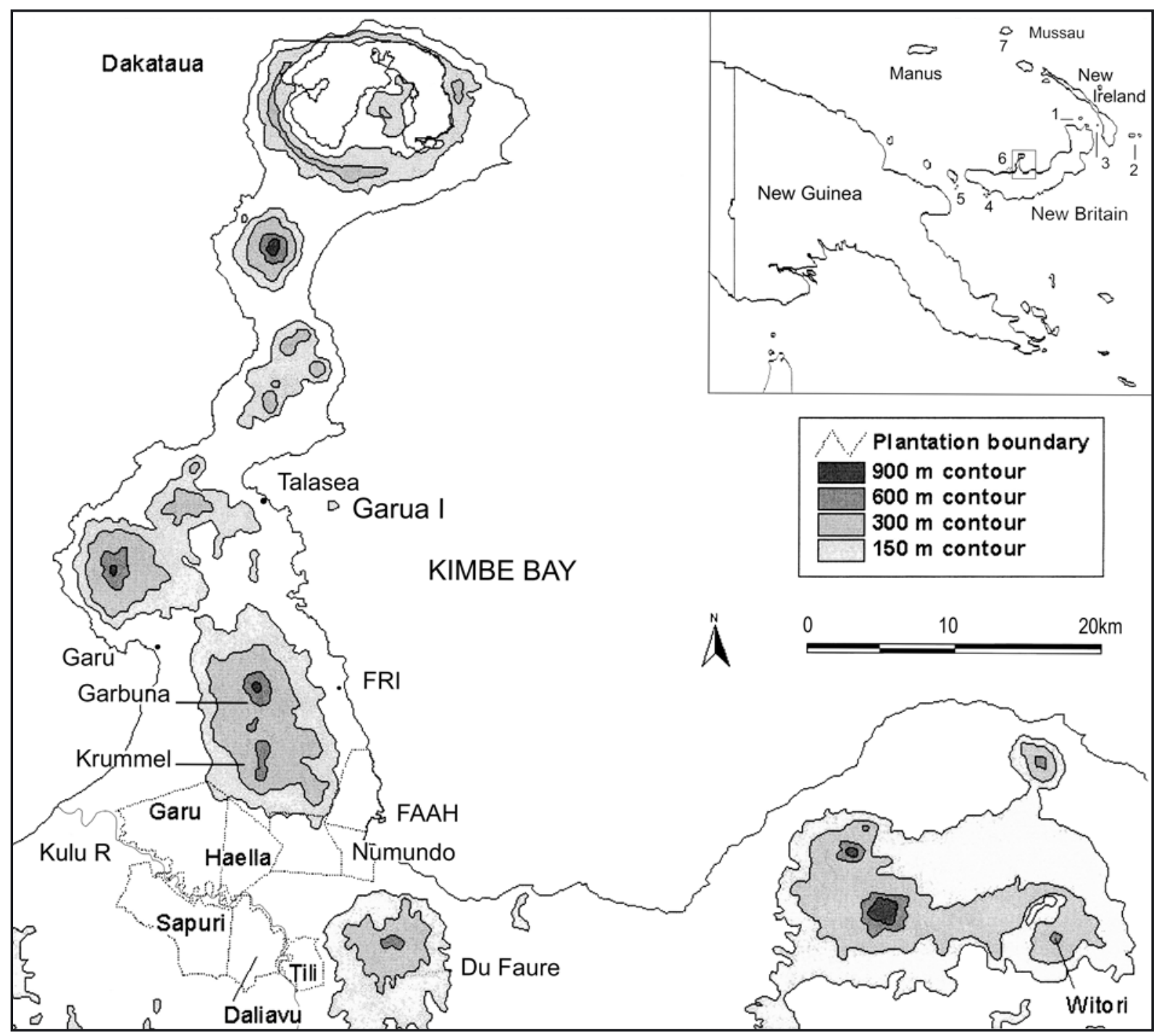

Figure 1. Map of the Willaumez Peninsula showing major volcanic centres, the boundaries of the plantations that formed the isthmus study region and other localities mentioned in the text. The inset shows the location of other Lapita pottery sites in the Bismarck Archipelago mentioned in the paper: 1 - Watom Island; 2 - Anir; 3 - Duke of York Islands; 4 - Arawe Islands; 5 - Siassi Islands; 6 - Kove Islands; 7 - Mussau Islands.

for at least 40,000 years and the more isolated islands to the east where Lapita dentate-stamped pottery marks initial human colonisation. Only five sites other than those on Garua are not at sea level or on small islands, and only two of these are not located on the Willaumez Peninsula mainland ${ }^{1}$.

Is Garua Island representative of a wider trend or is it a local anomaly, perhaps generated by the presence of obsidian on the island and / or its proximity to the major Kutau obsidian outcrops? In this paper we address this question with data derived from a new
Table 1. Distribution of test pits in the isthmus region of Willaumez Peninsula by landform and occurrence of pottery. The Table includes only those test pits where the ' $\mathrm{W}$-K2 soil' and/or pottery occur.

\begin{tabular}{lccc}
\hline Landform & $\begin{array}{c}\text { Pottery and } \\
\text { obsidian }\end{array}$ & $\begin{array}{c}\text { obsidian } \\
\text { only }\end{array}$ & Totals \\
\hline Coastal plain & 3 & 1 & 4 \\
Coastal hill & 5 & 4 & 9 \\
Coastal foothill & 0 & 4 & 4 \\
Divide & 3 & 1 & 4 \\
Inland foothill & 0 & 17 & 17 \\
Floodplain foothill & 1 & 8 & 9 \\
\hline Totals & $\mathbf{1 2}$ & $\mathbf{3 5}$ & $\mathbf{4 7}$ \\
\hline
\end{tabular}


landscape study in the isthmus region of the Willaumez Peninsula mainland. Our focus is on the nature and distribution of the ceramic finds. These new data substantiate the Garua findings and demonstrate that the widely held model of settlements concentrated on beaches and small offshore islands is likely to be a product of taphonomic factors and biased research practices. Consequently, the model is seriously flawed. Moving beyond the beach, however, we still find the pattern is not uniform. Explaining the differences in the timing and distribution of pottery on Garua Island and the mainland of Willaumez Peninsula will lead landscape research in new directions. We conclude that if archaeologists explicitly search for variation, there is much to learn about the nature of settlement and land-use throughout the region where Lapita pottery has been found.

\section{Volcanic landscapes}

Important changes in theory and method underpin the findings from Garua Island and the more recent mainland Willaumez Peninsula project. In the first place, the shift of focus from specific places to the whole landscape forces the research to move beyond individual sites and consider the entire area that was part of people's lives: i.e., where they travelled, exploited resources, conducted rituals, etc. To understand human behaviour during the time of Lapita pottery, it is important to study this wide range of activities. Even if settlements were concentrated in specific places, and this assumption needs to be tested, most subsistence tasks would have occurred elsewhere. A comprehensive analysis, therefore, must include the 'off-site' components of prehistoric lifeways.

This focus on landscapes requires new methodologies to search for a broad range of evidence of past human activities. The most important innovation is to look for archaeological evidence across a range of environmental zones, including those where settlement would not be expected. Following on from this shift in approach, a broader class of archaeological evidence becomes relevant (e.g., small lithic scatters, so-called 'stray finds,' and rock art).

The Pacific region poses many obstacles to landscape archaeology, the most difficult being the dense vegetation cover typical even of areas under cultivation. Another problem is the instability of the coastal zone, which creates taphonomic problems and difficulties with interpreting the source and date of surface scatters (e.g., Felgate 2003; Gosden and Webb 1994; Kirch 1988; Spriggs 1984; Wickler 2001). The Willaumez Peninsula and its offshore islands provide an excellent place to undertake landscape archaeology because some of these problems can be overcome. Firstly, the recent large-scale development of oil palm plantations has opened up a vast area for archaeological investigation on a scale and level of accessibility that were previously impossible (Boyd et al. 2005; Torrence 2002b; Torrence and Doelman in press). Archaeological reconnaissance began late in the development scheme, but was nevertheless able to monitor some freshly cleared areas, new road cuts, and deep trenches. Material disturbed by development activities has lost its stratigraphic integrity but still indicates an ancient human presence. Targeted excavations near these surface scatters occasionally helped place the finds into their original chronological setting.

Secondly, the volcanic history of the region has created a series of tephras, each of which has sealed and preserved a relatively short-lived landscape. The tephras are physically and chemically distinctive and can be easily identified in the field. Recent work has provided reasonably secure dates for the volcanic events that created these chronostratigraphic units (Petrie and Torrence in prep.). The resulting tephrostratigraphy provides a method of relative dating that can be used consistently over a significant portion of West New Britain (Torrence et al. 2000; Pavlides 2006). Research on Garua Island has already benefited from the use of tephras as chronologically secure marker horizons (Torrence 2002a; 
Torrence and Stevenson 2000). On the southern Willaumez Peninsula mainland additional Holocene tephras are preserved, thereby reducing the time elapsed between the discard of cultural materials and the burial of the land surface by the next tephra deposit (Torrence and Doelman in press).

\section{The isthmus region}

The Willaumez Peninsula of West New Britain province is characterised by an exceptionally high number of pottery localities attributable to the Lapita ceramic series (Anderson et al. 2001:Table 1; Specht and Torrence in press). Although most sites are situated on offshore islands, prior work indicated the potential for dentatestamped pottery to occur on the mainland away from the shoreline. The FRI site at Walindi Plantation is distinguished by its elevated inland position, extending over several ridges up to $95 \mathrm{~m}$ above sea level at about $1 \mathrm{~km}$ inland from the present coastline (Figure 1; Specht et al. 1991). The date of around 2300-1850 cal. BP for plain sherds excavated here is much later than the inland shift recorded on Garua Island, though surface finds of dentate-stamped sherds at FRI suggest an earlier phase of activity there (Specht and Torrence in press; Torrence et al. 1990). The site thus indicated that further exploration in the southern region of Willaumez Peninsula might prove fruitful.

The transect across the base of Willaumez Peninsula, termed the 'isthmus,' was selected because it enables a study of human land-use across a wide range of environmental zones, including beach, coastal plain, coastal and inland foothills, river floodplain, and coastal swamp. The study area

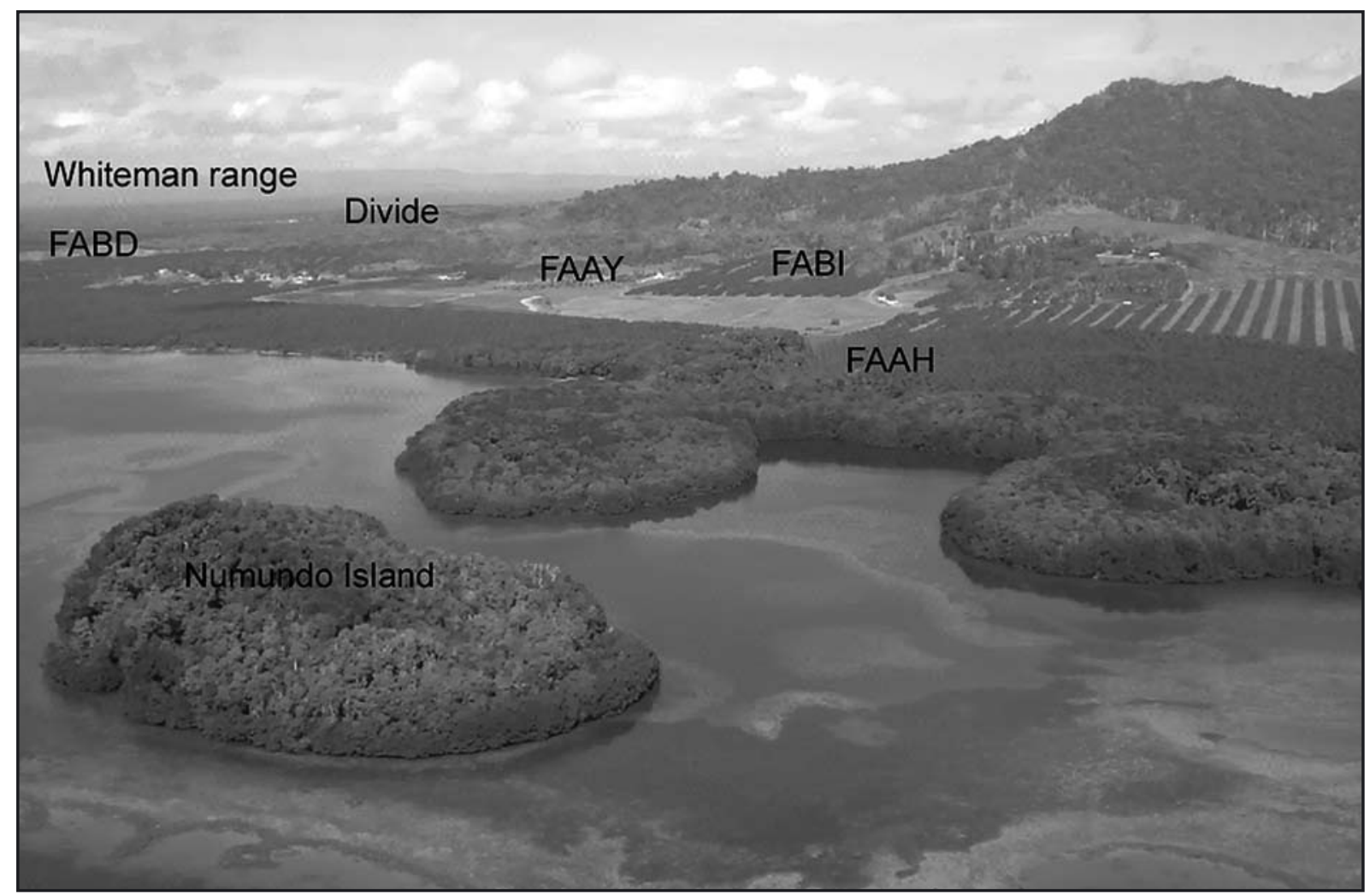

Figure 2. Aerial view from the west of Numundo Plantation and the divide separating the Kulu River floodplain and the Numundo coastal plain. Five localities with pottery are indicated: Numundo Island in the foreground, FAAH and FAAY on coastal hills, FABI on an inland foothill, and FABD on the divide. The peak of Mt Krummel at the extreme top right is partly concealed by cloud. The Whiteman Range is faintly visible on the horizon. Photo: courtesy of W.E. Boyd. 


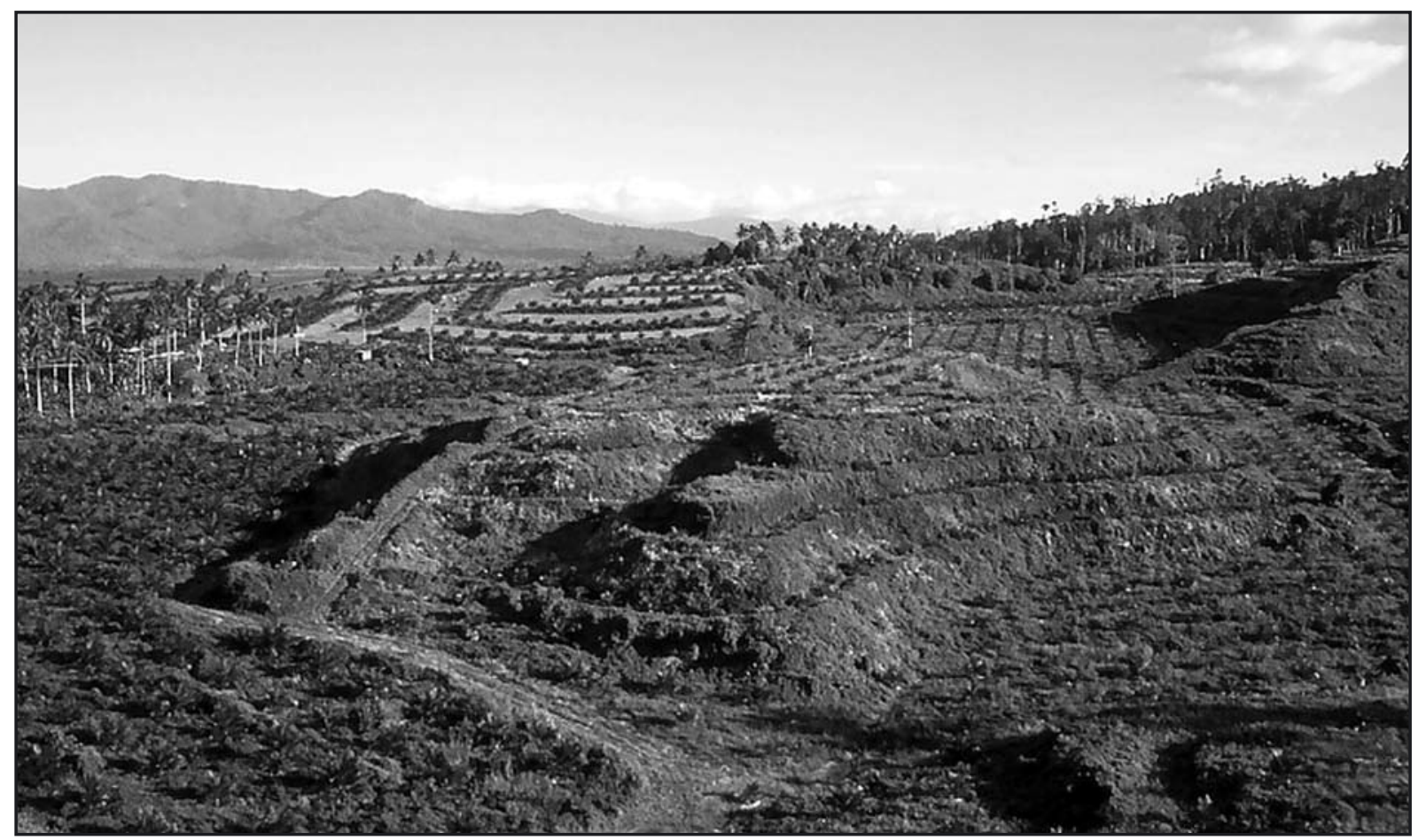

Figure 3. The divide between the Numundo coastal plain and the Kulu River floodplain showing the extent of landscape modification for plantation development in 1999, with the slopes of Mt Du Fauré on the horizon. Photo: J. Specht.

comprises the six oil palm plantations of Numundo, Haella, Tili, Garu, Daliavu and Sapuri developed by New Britain Palm Oil Ltd. These plantations, covering about $150 \mathrm{~km}^{2}$, lie between two Quaternary volcanoes, Mt Krummel $(854 \mathrm{~m})$ to the north and Mt Du Fauré $(752 \mathrm{~m})$ to the south (Figure 1). The two volcanoes are part of a series of more than a dozen Quaternary eruptive centres of the Kimbe Volcanics geological unit that forms the central spine of Willaumez Peninsula (Johnson and Blake 1972; McKee et al. 2005; Ryburn 1975). The base of the isthmus along the southwestern edge of our study area links with the northern foothills of the Whiteman Range of central New Britain that is partly formed by much older volcanic formations of Tertiary age (Ryburn 1975). Ridges of lava flows from Du Fauré, Krummel and Mt Garbuna ( $810 \mathrm{~m}$, located to the north of Krummel) coalesce on the isthmus to form a narrow divide less than $40 \mathrm{~m}$ high that separates the coastal plain of Numundo on the eastern side from the extensive floodplain of the Kulu River and its tributaries on the western side (Figures 2, 3).

The Kulu floodplain was swampy and difficult to access until it was cleared and drained for plantation development (Figures 4, 5). In contrast, the Numundo coastal plain is drier and has several perennial streams dissecting it, though prior to plantation development much of its seawards margin consisted of mangrove swamps (Boyd et al. 2005; Torrence 2002b). Several small hills rise to about 20 $\mathrm{m}$ above the coastal plain and one of these, Numundo Hill, stands on the western shore of Kimbe Bay facing Numundo Island (Figure 2). Several smaller hillocks $(<10 \mathrm{~m}$ ) on the coastal plain are remnants of late Pleistocene landscapes; at least one of these hillocks contains evidence for human activity prior to the Last Glacial Maximum (Torrence et al. 2004a).

The isthmus region today offers a diverse though dispersed range of habitats and resources for human utilisation, most of which were probably available during the period when Lapita pottery was used (Boyd et al. 2005). The Numundo coastal plain is relatively level and today provides easily accessible arable land, with swampy shorelines and nearby coral reefs. In contrast, the coast fronting the Kulu floodplain lacks reefs but is an important source of swamp resources for the people of Garu village at the northern 


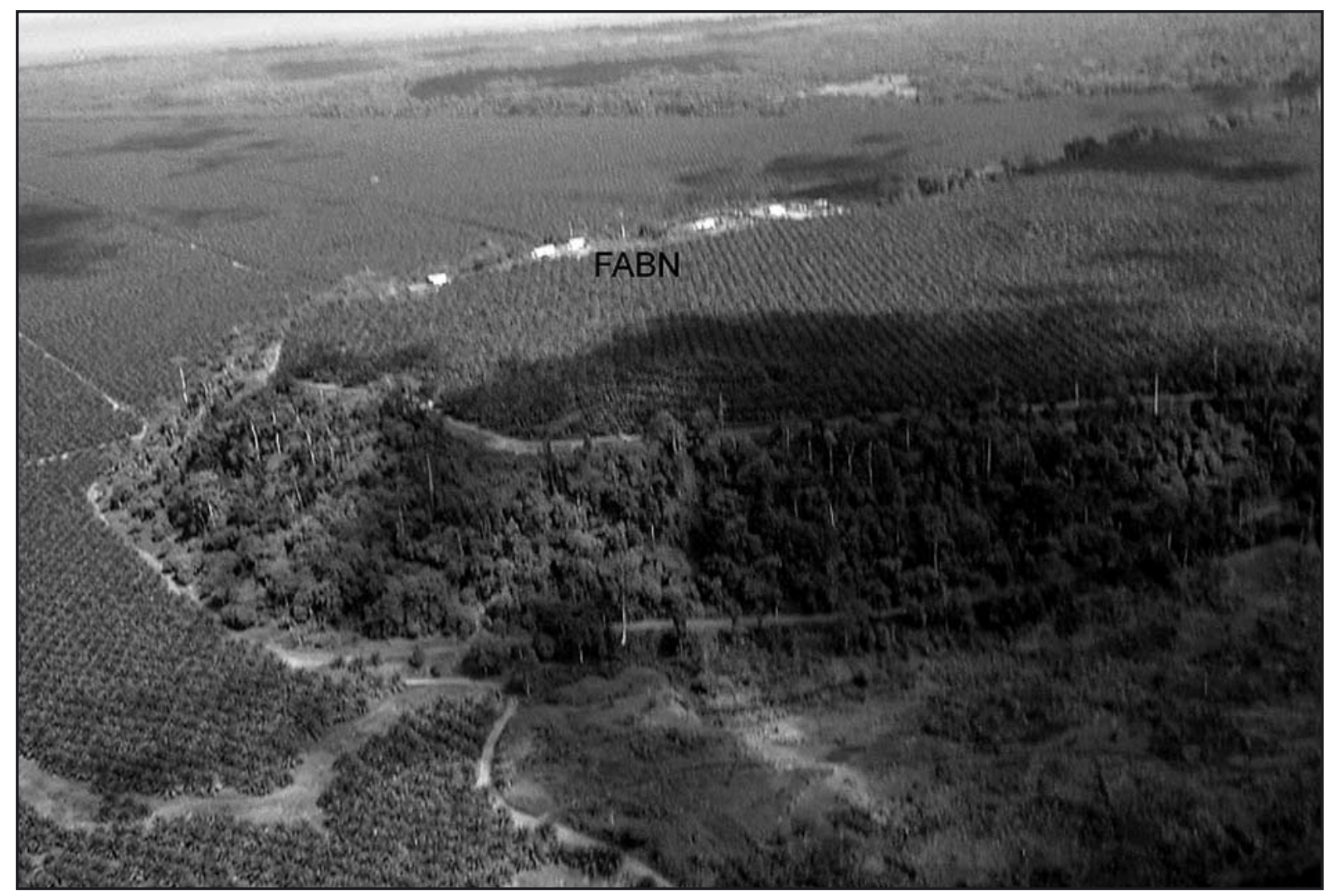

Figure 4. Aerial view from the east of Garu Plantation at the northern end of the Kulu River floodplain, with Boku Hill (FABN) in the centre. Dentate-stamped pottery was found in the bulldozed area around the pair of houses on the western edge of Boku Hill. Photo: courtesy of W.E. Boyd.

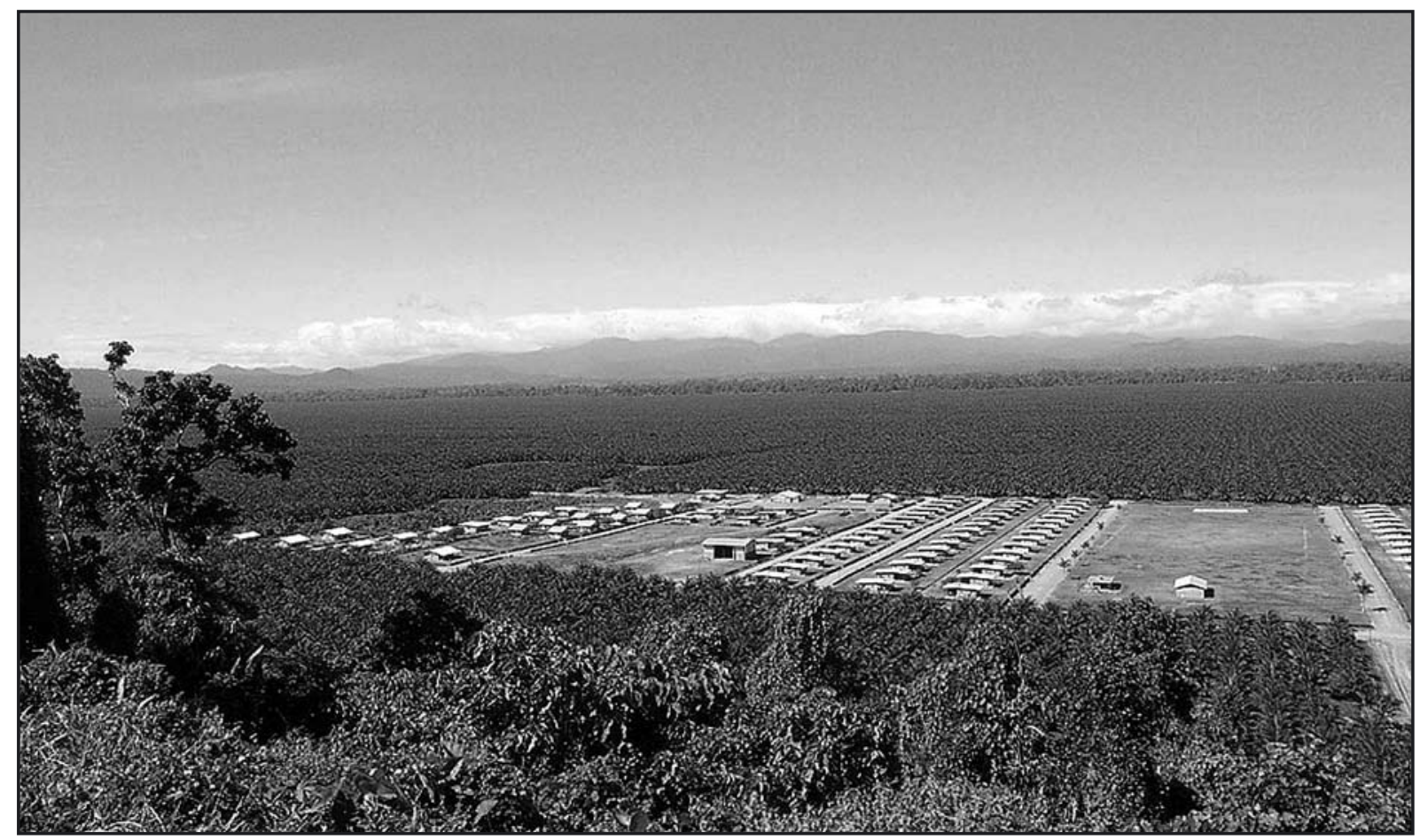

Figure 5. Looking south from the top of Boku Hill across Garu Plantation and the Kulu River floodplain towards Sapuri and Daliavu Plantations. The Whiteman Range in the distance is partly covered by clouds. Photo: R. Torrence. 
end of the floodplain. In the foothills of Mt Krummel and Mt Garbuna to the east of Garu village there are geothermal areas with megapode colonies, and additional geothermal areas occur within the crater of Garbuna (Johnson and Blake 1972). Mt Krummel and Mt Du Fauré are composed of highly porphyritic, low-silica andesites and dacites, whereas Garbuna has higher-silica bearing rocks. In the past all three volcanoes could have provided rock suitable for ground stone axe blades and other artefacts, though no quarries or production sites have yet been recorded. There are no obsidian outcrops in the isthmus region, but the Willaumez sources are only $25 \mathrm{~km}$ to the north, within one day's walking distance along the eastern coastal plain that extends almost to Talasea. The Mopir source at about the same distance to the southeast is accessible by land across rugged, steep hills and ridges of several volcanic complexes, whereas travel by sea or rivers would require a longer journey. Other rock resources are available in the more complex lithology of the Whiteman Range to the southwest of the isthmus.

\section{Tephrostratigraphy}

A key to the success of landscape archaeology in the isthmus region is the tephrostratigraphy composed of distinctive Holocene tephras from the Witori and Dakataua volcanic centres (Machida et al. 1996). For Lapita pottery the most important tephras are W-K2 (3480-3200 cal. BP) and W-K3 (1750-1550 cal. BP) (Petrie and Torrence in prep.). Dentate-stamped pottery is only found stratified between these two layers. The large W-K2 event was a major disaster that caused human populations to abandon the region for as much as 100 years or so. The landscape that was colonised by people making Lapita pottery was considerably altered by this event. The emplacement and subsequent erosion of the deep layer of W-K2 tephra extended the isthmus coastlines towards their present position. On the eastern side the tephra contributed to the conversion of coastal swamps and reef flats into the Numundo coastal plain. Similarly, on the western side of the isthmus the tephra infilled an earlier sea embayment and began the formation of the Kulu River floodplain (Boyd et al. 2005; Torrence and Doelman in press).

\section{Landscape sampling}

Archaeological research in the isthmus combined foot and vehicle surveys with a programme of test pitting to sample all environmental zones, although emphasis was placed on the older and well-preserved landscapes where the full stratigraphic record was preserved. Sixty-two $1-\mathrm{m}^{2}$ test pits were excavated, each identified by a Roman numeral (Figure 6). This strategy was supplemented by inspection of numerous exposures resulting from works associated with the development of the plantations, including drainage-channels, the terracing of slopes, and the construction of roads, housing and processing plants.

Palaeosols formed on the W-K2 tephra (hereafter 'the W-K2 soil') were present in 58 test pits, although artefacts were absent in 11 of these. Of the other 47 pits, $12(25 \%)$ contained pottery and obsidian artefacts whereas only obsidian was recovered from the other 35 (Table 1). Pottery was also recovered in surface collections at 12 localities. For analytical convenience, and with the exception of Numundo Island, these find spots are grouped into 14 wider areas that are allocated Papua New Guinea National Museum and Art Gallery four-letter site codes.

The sequence of tephras makes it possible to recognise situations where artefacts have been redeposited. These include test pits on the slopes and at the base of Numundo Hill (and, by implication, surface collections in the same areas), where most finds are almost certainly derived from the hilltop component of FAAH. The surface finds at FACR and FACQ were in areas disturbed by road construction 
and probably came from deposits that were completely removed by bulldozers, as no sherds were found in test pits excavated in adjacent undisturbed locations.

The distribution of test pits within different physiographic zones presented in Table 1 shows the broad spatial spread of material dating to the period between the W-K2 and W-K3 tephras. It is also interesting to note the large variation in the distance of the locations with pottery from the current coastline and their approximate elevation above present-day sea level (Table 2; elevations not adjusted for the 1 $\mathrm{m}$ or so of post-W-K2 tephra deposits). Numundo Island is the only beachside find spot, though pottery was recovered in trenches on the coastal plain below FAAH at depths close to or within the water table. Table 2 illustrates that pottery find spots occur on every major landform at elevations up to $80 \mathrm{~m}$ above sea level and up to $18 \mathrm{~km}$ inland from the current coastline; indeed, eight of the 14 locations are $2 \mathrm{~km}$ or more inland. FACZ is exceptional, as the 15 sherds found there were in a spring that waters a small taro garden at about $80 \mathrm{~m}$ above sea level on a foothill of Mt Krummel. Several test pits were excavated in the area surrounding the spring but none contained pottery. Three localities (FACQ, FACR, FADC) are on low spurs of the Whiteman Range foothills to the south of the Kulu River. These spurs are 17-18 km inland, and 17-20 $\mathrm{m}$ above sea level. Although the precise position of the coastline at the time of pottery use is unknown, these locations would have looked out across extensive swamps and tidal creeks and were not perched above ocean beaches. Significantly, perhaps, no pottery was recorded on the floodplain itself, although this landform was not intensively sampled as it was gradually built up after the W-K2 event and the water table is still high.

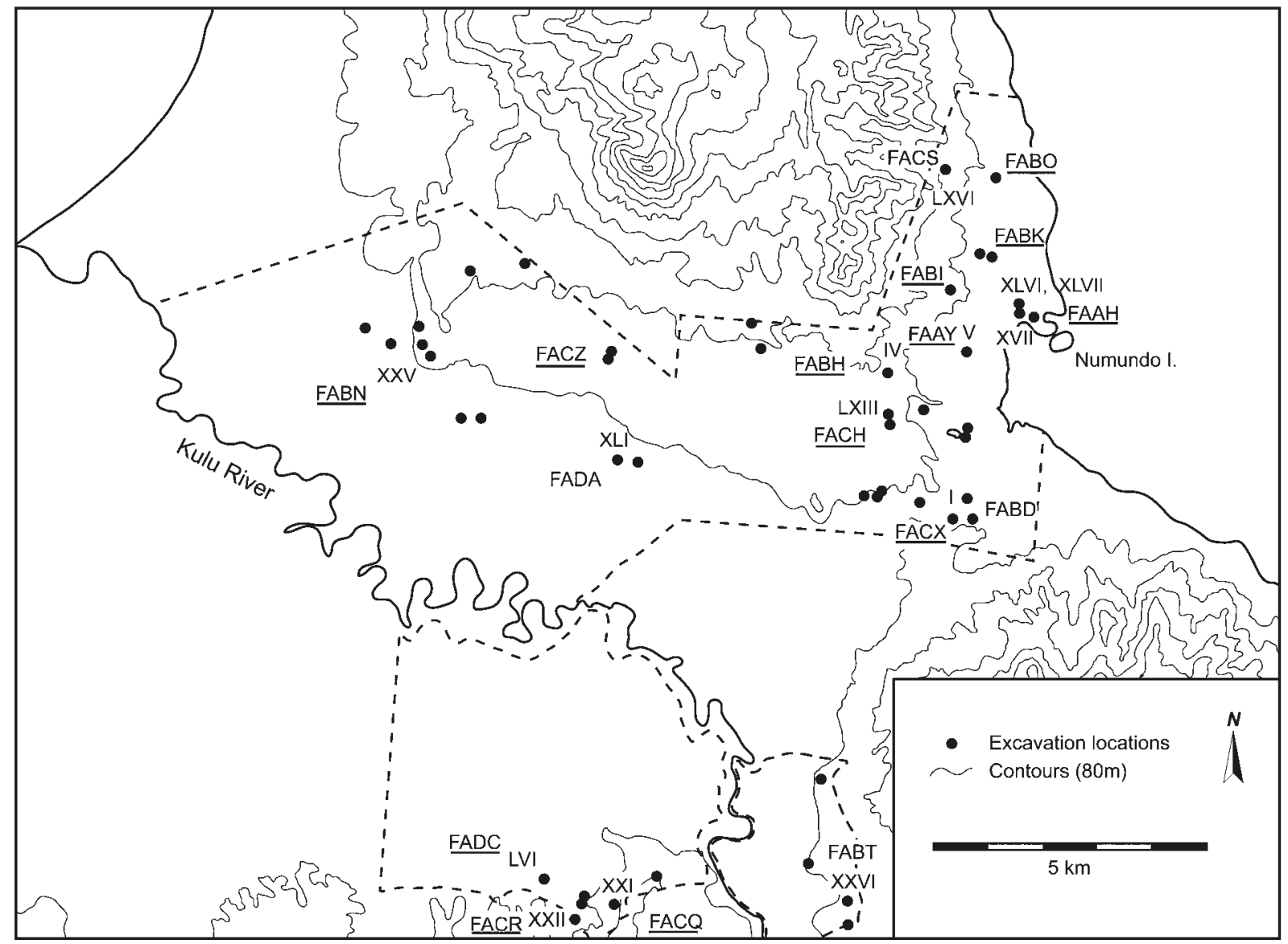

Figure 6. Distribution of test pits and locality codes in the isthmus region where the W-K2 soil was preserved. Roman numerals indicate test pit number; localities with pottery underlined. 
Table 2. Distribution of localities on the Willaumez Peninsula isthmus where pottery was recovered in excavated or surface contexts. The entries under ' $?$ ' indicate sherds with heavily weathered surfaces that might be decorated but the technique is not identifiable. Italicised entries for FAAH and FACU indicate totals for each locality.

\begin{tabular}{|c|c|c|c|c|c|c|c|c|c|c|c|c|c|c|c|c|}
\hline Locality & Landform & $\begin{array}{c}\text { Distance } \\
\text { to sea }\end{array}$ & Elevation & $\begin{array}{l}\text { Area or } \\
\text { trench }\end{array}$ & $\begin{array}{l}\text { Sherds } \\
\text { count }\end{array}$ & $\begin{array}{c}\text { Sherds } \\
\text { wgt }\end{array}$ & $\begin{array}{l}\text { Sherds } \\
\text { mean wgt }\end{array}$ & $\begin{array}{l}\text { Dentate } \\
\text { stamp }\end{array}$ & $\begin{array}{l}\text { Plain } \\
\text { stamp }\end{array}$ & Incised & $\begin{array}{l}\text { Circle } \\
\text { imp. }\end{array}$ & $\begin{array}{l}\text { Small } \\
\text { arcs }\end{array}$ & $\begin{array}{l}\text { Nail } \\
\text { imp. }\end{array}$ & $?$ & $\begin{array}{c}\text { Notch } \\
\text { lip }\end{array}$ & $\begin{array}{l}\text { Scallop } \\
\text { lip }\end{array}$ \\
\hline \multicolumn{17}{|l|}{ Excavated } \\
\hline \multirow[t]{6}{*}{ FAAH } & Coostal hill/ploin & $0.5-1 \mathrm{~km}$ & $20-40 \mathrm{~m}$ & oll strot. & 681 & 4075,6 & 6,0 & $21(? 23)$ & $15(? 16)$ & 10 & 3 & 0 & 1 & 6 & 24 & 6 \\
\hline & Coastal plain & $\sim 0.25 \mathrm{~km}$ & $\sim 1 \mathrm{~m}$ & VIII & 42 & 266,1 & 6,3 & $1(? 2)$ & 0 & 0 & 1 & 0 & 0 & 2 & 0 & 0 \\
\hline & Coastal hill & $\sim 0.25 \mathrm{~km}$ & $12 \mathrm{~m}$ & $X V I I$ & 575 & 3436,1 & 6,0 & 15 & $9(? 10)$ & 10 & 1 & 0 & 1 & 3 & 21 & 6 \\
\hline & Coastal hill & $\sim 0.5 \mathrm{~km}$ & $\sim 15 \mathrm{~m}$ & $X X V I I I$ & 15 & 225,7 & 15,1 & $4(? 5)$ & 3 & 0 & 1 & 0 & 0 & 0 & 1 & 0 \\
\hline & Coastal hill & $\sim 1 \mathrm{~km}$ & $21 \mathrm{~m}$ & XIVI & 47 & 133,4 & 2,8 & $1(? 2)$ & 3 & 0 & 0 & 0 & 0 & 1 & 2 & 0 \\
\hline & Coastal hill & $\sim 1 \mathrm{~km}$ & $21 \mathrm{~m}$ & $X L V \|$ & 2 & 14,3 & 7,2 & 0 & 0 & 0 & 0 & 0 & 0 & 0 & 0 & 0 \\
\hline FAAY & Coastal hill & $\sim 1.5 \mathrm{~km}$ & $16 \mathrm{~m}$ & V & 8 & 41,9 & 7,0 & 0 & 0 & 0 & 0 & 0 & 0 & 0 & 0 & 0 \\
\hline FABO & Coastal hill & $\sim 1.5 \mathrm{~km}$ & $20-40 \mathrm{~m}$ & XIV & 5 & 32,3 & 6,5 & 0 & 0 & 2 & 0 & 0 & 0 & 0 & 0 & 0 \\
\hline FABK & Coastal plain & $\sim 1.5 \mathrm{~km}$ & $19 m$ & VII & 1 & 51,4 & [51.4] & 0 & 0 & 1 & 0 & 0 & 0 & 0 & 0 & 0 \\
\hline FACX & Hill on divide & $\sim 2 \mathrm{~km}$ & $<40 \mathrm{~m}$ & XXXIIII & 4 & 10,4 & 2,6 & 0 & 0 & 0 & 0 & 0 & 0 & 0 & 0 & 0 \\
\hline \multirow[t]{3}{*}{ FACU } & Hill on divide & $\sim 2.5 \mathrm{~km}$ & $40-80 \mathrm{~m}$ & all strat. & 13 & 82,4 & 6,3 & 0 & 0 & 0 & 0 & 0 & 0 & 0 & 3 & 0 \\
\hline & Hill on divide & $\sim 2.5 \mathrm{~km}$ & $40-80 \mathrm{~m}$ & XXXI & 9 & 49,5 & 5,5 & 0 & 0 & 0 & 0 & 0 & 0 & 0 & 3 & 0 \\
\hline & Hill on divide & $\sim 2.5 \mathrm{~km}$ & $40-80 \mathrm{~m}$ & LXIII & 4 & 32,9 & 8,2 & 0 & 0 & 0 & 0 & 0 & 0 & 0 & 0 & 0 \\
\hline FADC & Floodplain hill & $\sim 17 \mathrm{~km}$ & $17-18 \mathrm{~m}$ & LVI & 3 & 4,3 & 1,4 & 0 & 0 & 0 & 0 & 0 & 0 & 0 & 0 & 0 \\
\hline \multicolumn{17}{|l|}{ Surface } \\
\hline Numundo Is. & Beach & 0 km & $0 \mathrm{~m}$ & n/a & 1 & 38,2 & {$[38.2]$} & 0 & (?1) & 1 & 0 & 0 & 0 & 0 & 0 & 0 \\
\hline \multirow[t]{2}{*}{ FAAH } & Coastal plain & $0.25 \mathrm{~km}$ & $1-5 m$ & $\operatorname{Locs} 5,6$ & 163 & 1503,8 & 9,2 & $2(? 3)$ & (?1) & 0 & 1 & 0 & 0 & 0 & 1 & 0 \\
\hline & Coastal hill & $0.25-0.5 \mathrm{~km}$ & $10-15 \mathrm{~m}$ & $\operatorname{Locs} 1,2$ & 19 & 380,6 & 20,0 & 2 & $1(? 2)$ & 2 & 0 & 0 & 0 & 0 & 0 & 1 \\
\hline $\mathrm{FABI}$ & Coastal hill & $\sim 1 \mathrm{~km}$ & $\sim 40 \mathrm{~m}$ & Area G & 2 & 2,7 & 1,4 & 0 & 0 & 1 & 0 & 0 & 0 & 0 & 0 & 0 \\
\hline FACU & Hill on divide & $\sim 2.5 \mathrm{~km}$ & $40-80 \mathrm{~m}$ & $02 / 01 C$ & 1 & 6,1 & [6.1] & 1 & 0 & 0 & 0 & 0 & 0 & 0 & 0 & 0 \\
\hline FABH & Hill on divide & $\sim 2.5 \mathrm{~km}$ & $40-80 \mathrm{~m}$ & Aгеа $\mathrm{E}$ & 7 & 30,6 & 4,4 & 0 & 0 & 0 & 0 & 0 & 0 & 0 & 0 & 0 \\
\hline FABN & Inland foothill & $\sim 6 \mathrm{~km}$ & $40-80 \mathrm{~m}$ & Loc. 1 & 8 & 40,3 & 5,0 & 1 & 0 & 0 & 0 & 0 & 0 & 0 & 2 & 0 \\
\hline $\mathrm{FACZ}$ & Inland foothill & $\sim 7 \mathrm{~km}$ & $\sim 80 \mathrm{~m}$ & spring & 15 & 371,1 & 24,7 & 5 & 0 & 0 & 0 & 3 & 0 & 0 & 0 & 0 \\
\hline FACR & Floodplain hill & $\sim 17.5 \mathrm{~km}$ & $19-20 \mathrm{~m}$ & $017 / 01$ & 11 & 40,3 & 3,7 & 2 & 0 & 0 & 0 & 0 & 0 & 0 & 0 & 0 \\
\hline FACQ & Floodplain hill & $\sim 18 \mathrm{~km}$ & $19-20 \mathrm{~m}$ & $01 / 12$ & 8 & 60,9 & 7,6 & 0 & 0 & 0 & 0 & 0 & 0 & 0 & 1 & 0 \\
\hline Totals & & & & & 950 & 6772,9 & & $34(? 38)$ & $16(? 20)$ & 17 & 4 & 3 & 1 & 6 & 31 & 7 \\
\hline
\end{tabular}

It is clear from the spatial distribution of obsidian and ceramics across the isthmus that landuse during the period between the W-K2 and W-K3 volcanic events was not limited to the coastal zone, thereby confirming the overall finding of the Garua study. To understand how this wide scale patterning compares to Garua Island and what it might represent in terms of the nature of human activities, we begin with an analysis of the pottery focusing on dating and potential types of activities represented at the locations where ceramics have been recovered. We then incorporate these findings into a broader analysis of settlement history in the isthmus region. 


\section{Radiocarbon dates}

Seventeen radiocarbon dates from test pits at 12 localities are presented in Table 3 (Figure 7). They are arranged in four groups according to whether sherds were (a) present in the dated levels, (b) present only in adjacent surface collections, (c) absent from the level dated but present below that, or (d) not present in either test pits or surface collections. A 'modern' result from FABO is omitted. All samples were fragments of charred nutshells (probably Canarium spp.) with growth spans not exceeding one year. Most of the age ranges were calibrated by Cameron Petrie (University of Cambridge) using the OxCal program as part of a larger Bayesian analysis of ${ }^{14} \mathrm{C}$ dates relating to Holocene volcanic eruptions and human activity on Willaumez Peninsula (details of this analysis will be reported elsewhere by Petrie and Torrence in prep.). The calibrated ranges marked by an asterisk are as supplied by the University of Waikato Radiocarbon Dating Laboratory. The age ranges are listed at $2 \sigma$ and represent the highest probability distribution at $95.4 \%$.

Three dates relate directly to dentate-stamped sherds. Those for FAAH / XVII (Wk-10463: 32102850 cal. BP; Wk-19190: 3070-2860 cal. BP) conform well to dates for this technique elsewhere in Near Oceania. Several conjoins of sherds in layer 9 of FAAH / XVII suggest minimum post-discard disturbance of this soil unit, though different degrees of weathering of sherds could indicate two phases of discard (compare Figures 8A-C with 8D-F). If this were so, the two dates indicate that the interval between the two phases was very short. For the present purpose the pottery from this layer is treated as belonging to

Table 3. Radiocarbon dates for archaeological materials recovered from the ' $\mathrm{W}-\mathrm{K} 2$ soil' in the test pits on the Willaumez Peninsula isthmus. All samples consisted of charred nutshell fragments. The calibrated age ranges are at $2 \sigma$ for the highest probability distribution (95.4\%) using the 0xCal program. The entry in square brackets for dentate-stamped pottery at FACU indicates that plain sherds were present in the test pit, but dentate-stamped sherds were present only in the surface collection.

\begin{tabular}{|c|c|c|c|c|c|c|c|c|c|}
\hline $\begin{array}{c}\text { Localities with or } \\
\text { without pottery }\end{array}$ & Landform & $\begin{array}{l}\text { Distance } \\
\text { from sea }\end{array}$ & $\begin{array}{c}\text { Elevation } \\
\text { a.s.l. }\end{array}$ & Trench & Layer & $\begin{array}{l}\text { Dentate } \\
\text { present }\end{array}$ & Lab code & $\begin{array}{l}\text { Reported } \\
\text { age }\end{array}$ & $\begin{array}{c}2 \sigma \text { calibrated } \\
\text { range } \\
(95.4 \%) \\
\end{array}$ \\
\hline \multicolumn{10}{|l|}{ In dated level } \\
\hline FADC & Floodplain hill & $\sim 17 \mathrm{~km}$ & $17-18 m$ & LVI & 9 spit 3 & no & Wk-12845 & $2963 \pm 47$ & $3240-2960$ \\
\hline FAAH & Coastal hill & $0.25 \mathrm{~km}$ & $12 \mathrm{~m}$ & $X V I I$ & 9 spit 1 & yes & Wk-10463 & $2880 \pm 59$ & $3210-2850$ \\
\hline "FAAH & Coastal hill & $0.25 \mathrm{~km}$ & $12 \mathrm{~m}$ & $X V I I$ & 9 spit 3 & yes & Wk-19190* & $2847 \pm 34$ & $3070-2860$ \\
\hline FACU & Hill on divide & $\sim 2.5 \mathrm{~km}$ & $40-80 \mathrm{~m}$ & LXIII & 7 spit 1 & [yes] & Wk-12834 & $2473 \pm 48$ & $2720-2360$ \\
\hline FAAY & Coastal hill & $\sim 1.5 \mathrm{~km}$ & $16 \mathrm{~m}$ & V & 7 spit 1 & no & Wk-9026 & $2472 \pm 57$ & $2720-2360$ \\
\hline FAAH & Coastal hill & $\sim 0.25 \mathrm{~km}$ & $21 \mathrm{~m}$ & XLVI & 3 spit 1 & yes & Wk-12824 & $2055 \pm 56$ & $2300-1900$ \\
\hline \multicolumn{10}{|l|}{ On surface only } \\
\hline FACQ & Floodplain hill & $\sim 18$ km & $19-20 \mathrm{~m}$ & $X X I$ & 4 spit 1 & no & Wk-10478 & $2883 \pm 63$ & $3210-2850$ \\
\hline FACR & Floodplain hill & $\sim 17.5 \mathrm{~km}$ & $19-20 \mathrm{~m}$ & XXII & 8 spit 1 & yes & Wk-10459 & $2831 \pm 57$ & $3110-2780$ \\
\hline FABN & Inland foothill & 6 km & $40-80 \mathrm{~m}$ & $X X V$ & 6 spit 1 & yes & ANSTO 0ZF-110 & $2280 \pm 30$ & $2360-2160$ \\
\hline FABH & Hill on divide & $\sim 2.5 \mathrm{~km}$ & $40-80 \mathrm{~m}$ & IV & 3 spit 2 & no & Wk-10471 & $2182 \pm 61$ & $2340-2040$ \\
\hline \multicolumn{10}{|c|}{ Not in dated level but present below } \\
\hline "FAAH & Coastal hill & $0.25 \mathrm{~km}$ & $21 \mathrm{~m}$ & XLVII & 4 spit 1 & n/a & Wk-19189* & $2301 \pm 33$ & $2360-2160$ \\
\hline FADC & Floodplain hill & $\sim 17 \mathrm{~km}$ & $17-18 \mathrm{~m}$ & LVI & 9 spit 1 & $\mathrm{n} / \mathrm{a}$ & Wk-19188: & $2199 \pm 34$ & $2330-2130$ \\
\hline \multicolumn{10}{|l|}{ No pottery at all } \\
\hline FADA & Floodplain hill & $\sim 7 \mathrm{~km}$ & $\sim 80 \mathrm{~m}$ & XLIV & 5 spit 1 & n/a & Wk-12840 & $2965 \pm 46$ & $3240-2970$ \\
\hline FACS & Coastal foothill & $\sim 2 \mathrm{~km}$ & $40-80 \mathrm{~m}$ & LXVI & 5 spit 2 & n/a & Wk-12831 & $2535 \pm 45$ & $2760-2460$ \\
\hline FABT & Inland foothill & $\sim 24 \mathrm{~km}$ & $\sim 40 \mathrm{~m}$ & $X X V I$ & 7 spit 2 & n/a & Wk-10470 & $2272 \pm 70$ & $2470-2110$ \\
\hline FABD & Coastal foothill & $\sim 2 \mathrm{~km}$ & $\sim 40 \mathrm{~m}$ & I & 8 spit 2 & n/a & Wk-19191" & $2251 \pm 39$ & $2350-2150$ \\
\hline FABD & Coastal foothill & $\sim 2 \mathrm{~km}$ & $\sim 40 \mathrm{~m}$ & I & 8 spit 3 & n/a & ANSTO 0ZF-109 & $2250 \pm 40$ & $2350-2150$ \\
\hline
\end{tabular}




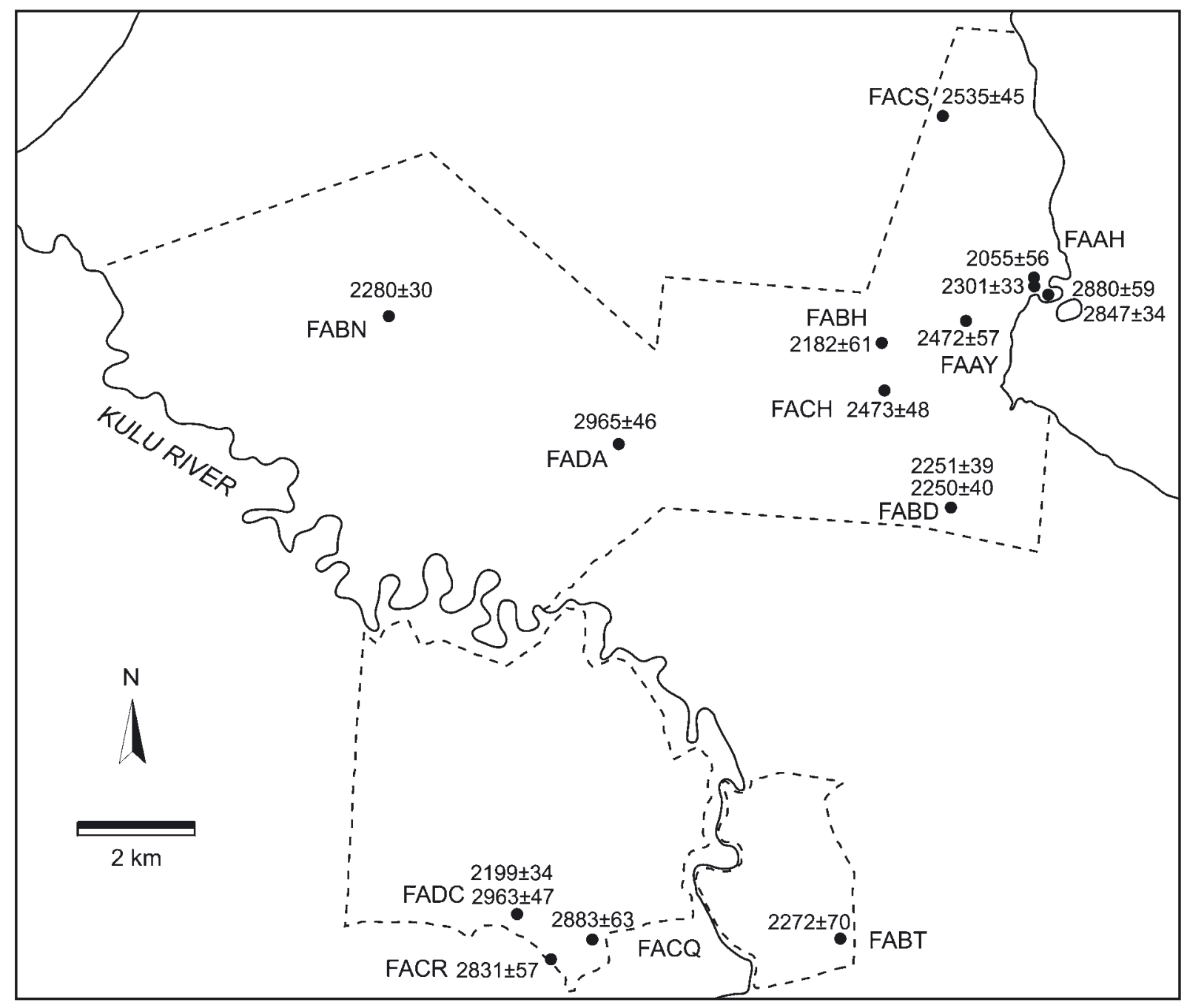

Figure 7. Distribution of radiocarbon dates for cultural materials recovered from the W-K2 soil on the Willaumez Peninsula isthmus.

a single depositional phase. The other sample (Wk-12824: 2300-1900 cal. BP) relates to a dentate-stamped sherd in the top of the W-K2 soil at FAAH/XLVI. This sherd is contemporary with aceramic levels at FABN and FABH, where sherds (including one with dentate-stamping at FABN) were recovered in surface collections. All the sherds in FAAH/ XLVI are moderately to heavily weathered and small, with a low mean weight $(2.9 \mathrm{~g})$. While not ruling out the possibility of a lag deposit or some degree of post-depositional disturbance, we tentatively accept the dating result at this stage. It is important to note that the sherds were stratified between the $\mathrm{W}-\mathrm{K} 2$ and $\mathrm{W}-\mathrm{K} 3$ tephras, so any post-depositional disturbance must have occurred during this limited time period. We note, furthermore, that the date matches six others for nonpottery contexts. The implications for the end of the Lapita ceramic series raised by sample Wk-12824 will be discussed further in the final report on the isthmus pottery (Specht and Spry in prep.). 


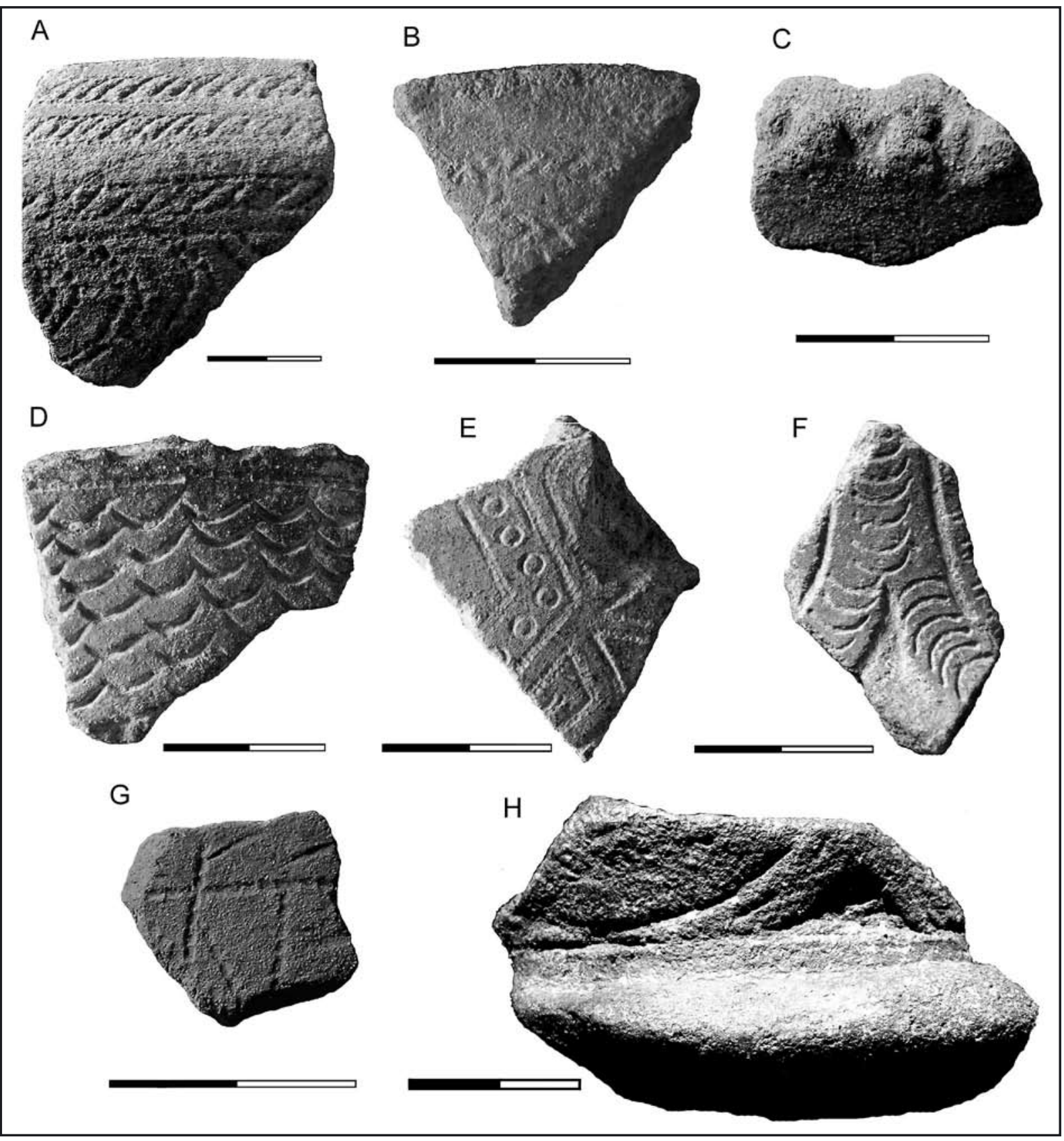

Figure 8. Sherds from FAAH and Numundo Island on Willaumez Peninsula isthmus. Scale bars equal to $20 \mathrm{~mm}$. A: FAAH/35, XVII layer 9 spit 2; carinated shoulder, dentate-stamped. B: FAAH/27, XVII layer 9 spit 2; form I? rim, dentate-stamped. C: FAAH/46, XVII layer 9 spit 2; carinated shoulder, fingernail impressed. D: FAAH/36, XVII layer 9 spit 2; body, dentate- and plain arc stamped. E: FAAH/28, XVII layer 9 spit 2; body, dentate-stamped and plain circle impressed. F: FAAH/38, XVII layer 9 spit 2; body, plain arc stamped and carved surface. G: FAAH/62, XVII layer 9 spit 2; body, dentate-stamped. H: Numundo Island, surface; cylinder stand fragment, incised, plain arc or straight-line stamped on flange, deeply incised and carved body.

\section{The pottery}

Although our focus in this paper is on the Lapita ceramic series, it is worth noting four sherds of unusual style or dating to more recent periods. Two incised sherds in Layer 9 at FABO/XIV are of uncertain affiliation and age, but could be part of the late incised component of the Lapita ceramic series (Figures 9A, 9B). An incised Type X sherd (Figure 9C; Lilley 1988) found on the surface of FABI indicates pottery use around 1000-500 cal. 


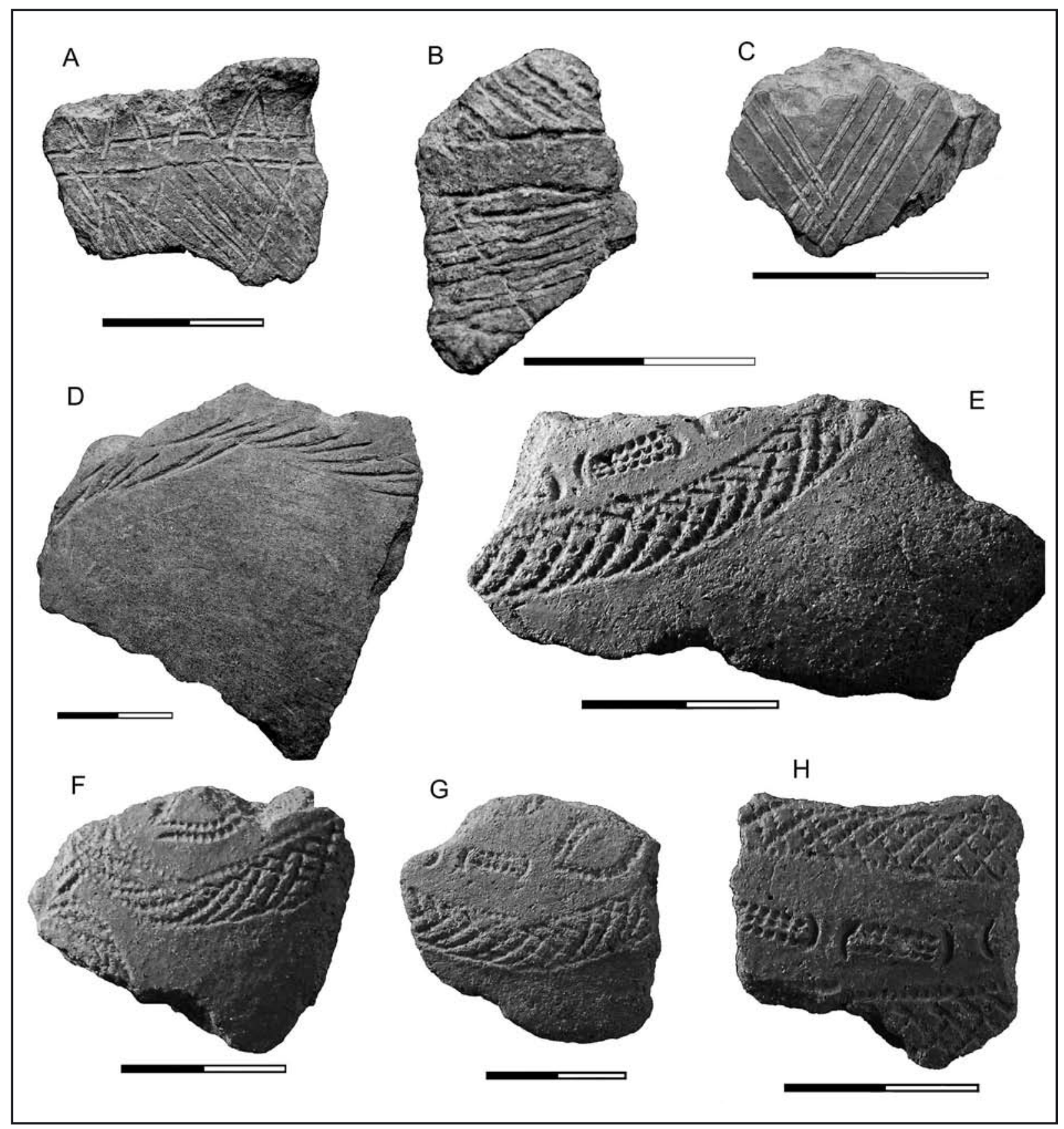

Figure 9. Sherds from pottery localities on the Willaumez Peninsula isthmus. Scale bars equal to $20 \mathrm{~mm}$. A: FABO/1, XIV layer 9 spit 1; rim/neck (form uncertain), incised. B: FABO/2, XIV layer 9 spit 2; body, incised. C: FABI/1, surface; body, incised, Type X; 10R 3/6 dark red. D: FABK/1, VII W-K2 soil; body, incised. E: FACZ/3, surface; body, dentate-stamped; 10R 4/6 red. F: FACZ/1, surface; body, dentate-stamped, and plain arc and circle impressed; $2.5 \mathrm{R} 4 / 4$ reddish brown. G: FACZ/4, surface; body, dentate- and plain arc stamped, circle impressed. H: FACZ/2, surface; body, dentate- and plain arc stamped, circle impressed; $10 \mathrm{R} 4 / 6$ red.

BP (Lilley and Specht in press), and therefore after the W-K3 event. This is the first documentation of Type X in the Willaumez Peninsula area. Another incised sherd with an unusual design in the W-K2 soil at FABK/ VII (Figure 9D) is of unknown age and affiliation.

The remaining 947 excavated and surface sherds that are likely to belong to the Lapita ceramic series are summarised in Tables 2 and 4 in terms of decoration and form. Sample sizes are generally small. With the exception of FAAH, the largest number of sherds at any locality is 15 at FACZ and most localities yielded fewer than ten. In contrast, there were dense concentrations of sherds at FAAH, representing 
over $90 \%$ (862) of all sherds recovered on the isthmus. Most of these (575) came from Layer 9 of test pit XVII. The sample is thus heavily biased towards FAAH, but the smaller collections from other localities contribute significant information about past land-use.

No detailed fabric analysis has yet been carried out, but preliminary inspection suggests that most sherds have volcanic sand and lithic fragments up to 1-3 $\mathrm{mm}$ in length, and a few may have calcareous inclusions. The eight surface sherds from FACQ, from a single pot, appear to lack volcanic sand or lithic fragments. These sherds are thin and hard, and include a notched rim with an unusual brownish-yellow surface colour (Munsell 10YR 6/6) that is probably the result of the fabric composition or firing conditions rather than the application of pigment (Figure 10F).

Vessel forms include seven of the eight forms proposed by Summerhayes (2000) for the Arawe Islands, plus a probable cylinder stand (Table 4). The most common and widespread forms are roundbodied jars with everted rims (V and VI), jars with incurving upper body and vertical rims (VII), and open bowls (I) (Figure 10). Not surprisingly, FAAH has the widest range of forms (7). Two angular sherds at FAAH are from flat-based open bowls. Carinated shoulders (7 examples) occur only at FAAH, where round shoulders are more common (15); there is also one round shoulder at FACU. At FAAH the carinated shoulders are statistically significantly thicker than round shoulders, though there is no statistical difference in thickness between plain shoulders and those with dentate - or plain-stamped decoration (Student's- $t$ test, two-tail, $\mathrm{p}=0.4251$ ). The Numundo Island sherd has a prominent rounded flange, and we identify this as part of a cylinder stand (Figures 8H, 10G; cf. Best 2002:82, Fig. 25). No pot stands (Summerhayes Form VIII) have been identified in the samples.

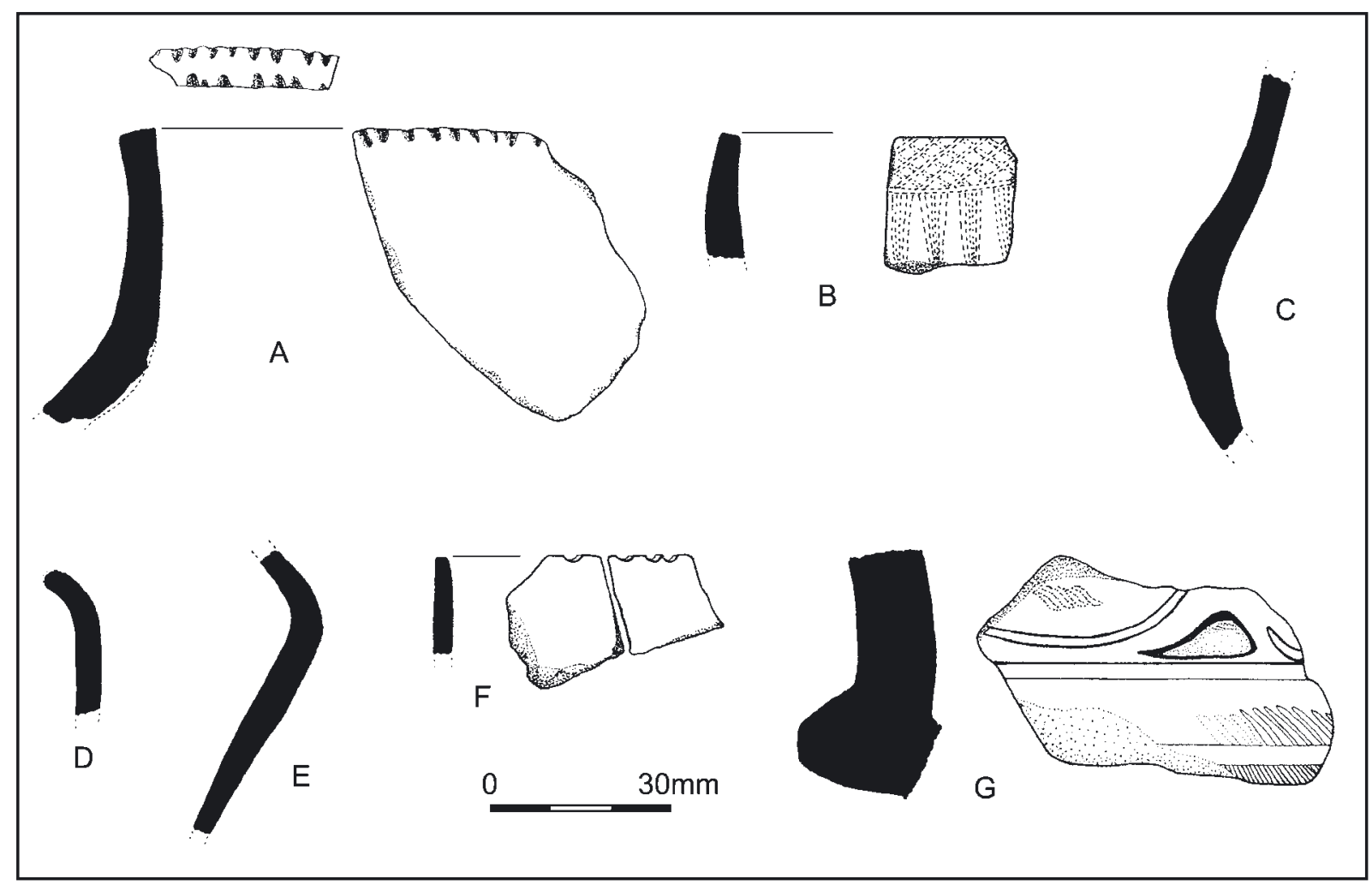

Figure 10. Sherds from pottery localities on the Willaumez Peninsula isthmus. A: FABN/1, surface; form VII double-notched rim. B: FABN/2, surface; form I rim, dentate-stamped. C: FACU/9, XXXI layer 6 spit 2; form V? rounded shoulder/neck, plain. D: FABO /1, XIV layer 9 spit 1, rim (form uncertain), incised (Plate 5A). E: FAAY /1, V layer 7 spit 2 (below Wk-9026: 2472 557 ); form V neck, plain. F: FACQ/1, surface; form V or VI rim, plain, 10R 6/6 brownish yellow. G: Numundo Island, surface; cylinder stand fragment, incised, plain arc stamped and carved. 
Table 4. Distribution of vessel forms at the Willaumez Peninsula isthmus pottery localities. The FAAH forms include sherds from the base of the hill.

\begin{tabular}{|c|c|c|c|c|c|c|c|c|c|c|c|c|c|}
\hline Locality & Landform & I & $\begin{array}{c}\text { I } \\
\text { flat base }\end{array}$ & II & III & IV & V & VI & VII & VIII & $\begin{array}{l}\text { Cylinder } \\
\text { stand }\end{array}$ & $\begin{array}{l}\text { Total } \\
\text { sherds }\end{array}$ & $\begin{array}{l}\text { Total } \\
\text { forms }\end{array}$ \\
\hline Numundo Island & Beach & 0 & 0 & 0 & 0 & 0 & 0 & 0 & 0 & 0 & 1 & 1 & 1 \\
\hline FAAH & Coastal hill & 4 & 2 & 1 & 1 & 1 & 2 & 0 & 5 & 0 & 0 & 16 & 7 \\
\hline FAAY & Coastal hill & 0 & 0 & 0 & 0 & 0 & 2 & 0 & 0 & 0 & 0 & 2 & 1 \\
\hline $\mathrm{FABI}$ & Coastal hill & 0 & 0 & 0 & 0 & 0 & 0 & 0 & 0 & 0 & 0 & 0 & 0 \\
\hline FABK & Coastal hill & 0 & 0 & 0 & 0 & 0 & 0 & 0 & 0 & 0 & 0 & 0 & 0 \\
\hline FABO & Coastal hill & 0 & 0 & 0 & 0 & 0 & 1 & 0 & 0 & 0 & 0 & 1 & 1 \\
\hline FACX & Coastal hill & 0 & 0 & 0 & 0 & 0 & 0 & 0 & 0 & 0 & 0 & 0 & 0 \\
\hline$\overline{\mathrm{FABH}}$ & Hill on divide & 0 & 0 & 0 & 0 & 0 & 0 & 0 & 0 & 0 & 0 & 0 & 0 \\
\hline FACU & Hill on divide & 0 & 0 & 0 & 0 & 0 & 0 & 0 & 0 & 0 & 0 & 0 & 0 \\
\hline FABN & Inland foothill & 1 & 0 & 0 & 0 & 0 & 0 & 0 & 1 & 0 & 0 & 2 & 2 \\
\hline FACQ & Inland foothill & 0 & 0 & 0 & 0 & 0 & 2 & 0 & 0 & 0 & 0 & 2 & 1 \\
\hline FACR & Inland foothill & 0 & 0 & 0 & 0 & 0 & 0 & 1 & 0 & 0 & 0 & 1 & 1 \\
\hline $\mathrm{FACZ}$ & Inland foothill & 0 & 0 & 0 & 0 & 0 & 0 & 0 & 0 & 0 & 0 & 0 & 0 \\
\hline FADC & Inland foothill & 0 & 0 & 0 & 0 & 0 & 0 & 0 & 0 & 0 & 0 & 0 & 0 \\
\hline Totals & & 5 & 2 & 1 & 1 & 1 & 7 & 1 & 6 & 0 & 1 & 25 & $8(9)$ \\
\hline
\end{tabular}

Surface modifications include pigments or slips that mostly (14 of 15) fall within the red ranges (Munsell 7.5R 4/8; 10R 4-5/6-8). A reddish-brown (2.5R 4/4) body sherd at FACZ may reflect postdepositional surface alteration, as it appears to come from the same vessel as the red sherds. Whereas some red-pigmented sherds have a matte finish, others (including dentate-stamped sherds) appear to have been burnished. There is no evidence for the application of a white infill or coating on dentatestamped sherds as noted elsewhere (Bedford 2006; Green and Anson 2000:Fig. 14I).

Decoration is confined to the rim-upper body-shoulder areas, with few rims decorated on their interior surface (Figure 11D). The main technique, dentate-stamping, is twice as common as plainstamping and linear incision. The dentate impressions are generally medium to large in size, though one surface sherd at FAAH has much finer impressions (Figure 11G). Impressed circles (4 examples) occur only at FAAH (Figures $8 \mathrm{E}, 11 \mathrm{~A}$ ). Small plain-impressed arcs are present only at FACZ, where they close the ends of groups of short dentate-stamped lines (Figures 9E, 9G, 9H). The category 'incised' includes several sherds at FAAH and that from Numundo Island where the incision forms a broad, shallow groove with rounded cross-section. A body sherd at FAAH and the possible cylinder stand fragment from Numundo Island have part of the surface carved away, putting the decorated surface into bas-relief (Figures 8F, 8H, 10G). The only example of fingernail impressions is on a carinated shoulder in Layer 9 at FAAH/XVII (Figure 8C).

Lip modifications consist primarily of notching or wavy scalloped impressions, usually on flat lips, with scalloped lips present only at FAAH (6 excavated, 1 surface). Single-notched lips (25) outnumber double-notched lips (6). Both occur at FAAH (20 single, 5 double) and FABN (1 each), but only single notching is present at FACQ (1) and FACU (3) (Figures 10A, 10F). There are two definite and two possible examples of dentate-stamped lips at FAAH, where the designs consist of triangles and arcs, and alternating groups of diagonal lines and plain-stamped arcs (Figure 11D). There are no applied plain or notched relief bands (other than the flange on the Numundo Island sherd), applied relief knobs, excised triangles, cut-outs, punctations or shell-edge impressions. 


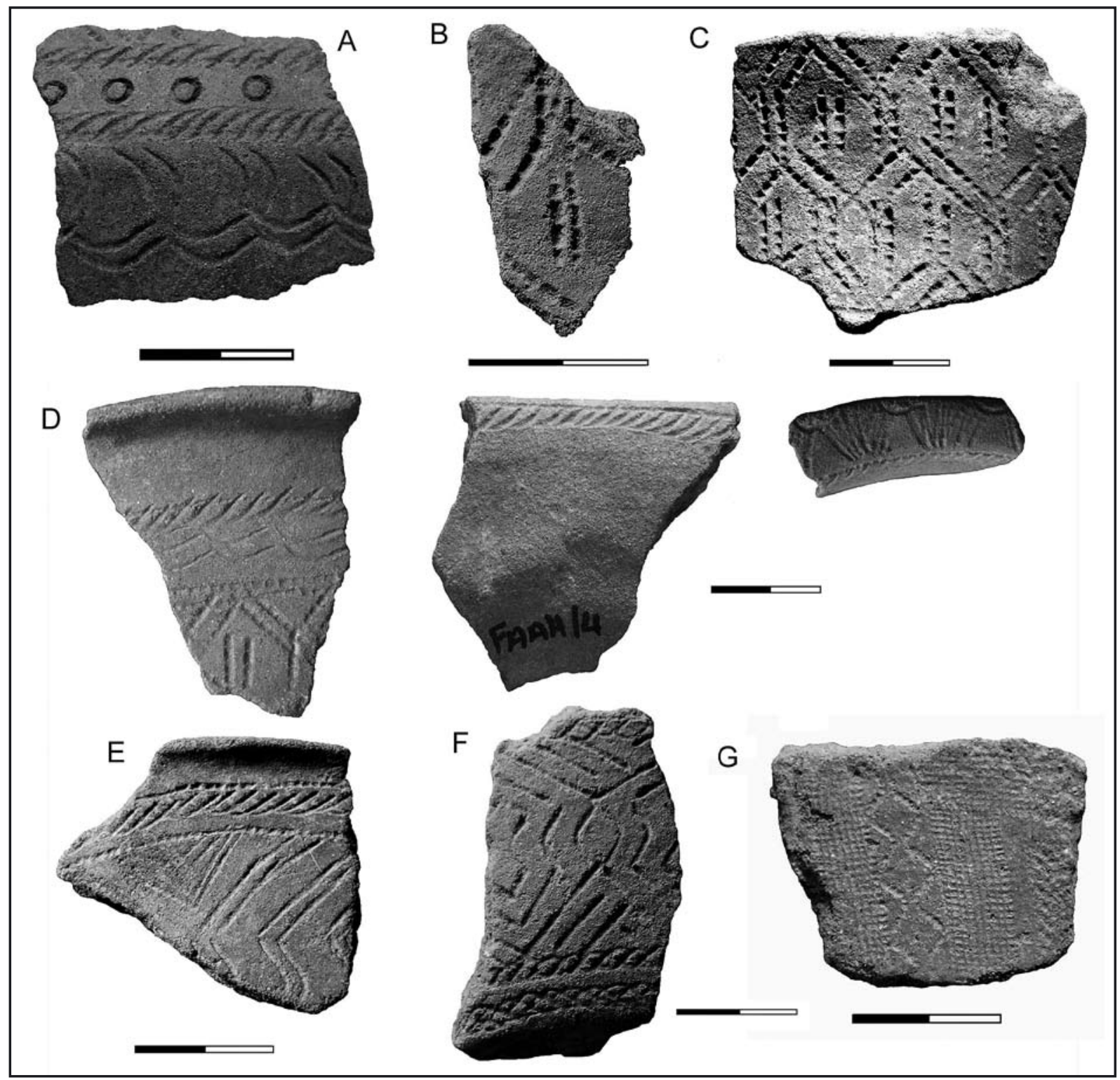

Figure 11. Selected sherds from FAAH on Willaumez Peninsula isthmus. Scale bars equal to $20 \mathrm{~mm}$. A: FAAH/91, XXVIII W-K2 soil; carinated shoulder, incised, plain arc stamped, impressed circles. B: FAAH/98, XXVIII W-K2 soil; body, dentate-stamped. C: FAAH/92, XXVIII W-K2 soil; body, dentate-stamped. D: FAAH/4, XXVIII W-K2 soil; form IV rim (exterior, interior, rim/lip), dentate- and plain arc stamped. E: FAAH/1, surface; form I? rim, dentate-stamped and incised/plain arc stamped. F: FAAH/2, surface; probable flat-based bowl, dentate-stamped. G: FAAH/102, surface; body, dentate-stamped; 7.5R 4/8 red.

The designs are primarily rectilinear, but many decorated sherds are too small to identify their motifs with certainty. Dentate - and plain-stamped motifs include narrow bands of overlapping arcs forming zone markers that often separate groups of other repeated elements including rows of arcs and rectilinear compositions (e.g., Figures 8A, 8D, 11D, 11F) and two examples of triangles formed by dentate-stamped lines (Figures 10B, 11D). There are no obvious faces or 'earplugs', though one sherd at FAAH (Figure 8E) could have a section of the 'labyrinth' design (Siorat 1990:62) that occasionally appears as a 'space-filler' between faces (Spriggs 1990). The incised sherds at FAAH indicate groups of parallel straight and curved lines that commonly occur with dentate-stamped designs at other Lapita sites (see refs in Specht and Summerhayes in press; Specht and Torrence in press). 


\section{Comparison with the Talasea area}

The isthmus sherds show both similarities and contrasts with those of the Talasea area (Table 5). The differences may be due partly to the small sample sizes for the isthmus, but could also reflect temporal and behavioural variations. Around Talasea, the earliest dentate-stamped pottery at FYS (Torrence and Stevenson 2000: Table 1) and FEA (White et al. 2002) are located at beach level. On the isthmus, only the cylinder stand sherd from Numundo Island comes from a similar location. At ECA/B in the Mussau Islands a cylinder stand is dated to about the same time or slightly later than FYS while overlapping substantially with Wk-10463 for FAAH / XVII (Kirch 2001a). On the other hand, Wk-10463 (3210-2850 cal. BP) and Wk-19190 (3070-2860 cal. BP) are slightly younger than the oldest date of 3390-3080 cal. BP at FYS (Beta-72144; Specht and Torrence in press: Table 5). We suggest, then, that there could be a small but important difference in age between FAAH/XVII and the Numundo Island beach find, and this might explain the scarcity of fine, needlepoint dentate-stamping at the

Table 5. Comparison between FAAH and the Talasea area in terms of selected pottery attributes. For the age ranges ' $(\mathrm{P})^{\prime}$ indicates plant samples, '(S)' indicates shell sample.

\begin{tabular}{|c|c|c|c|c|c|c|}
\hline & FCR/FCS & FEA & FEA & FAAH & FSZ & FAO \\
\hline Location & Garua Harbour & Garua Harbour & Garua Harbour & Isthmus & Garua Harbour & Garua Harbour \\
\hline Landform & Beach/intertidal & Beach level & Beach/intertidal & Coastal hill & Coastal hill & Coastal hill \\
\hline Number of sherds & $\sim 750$ & $>8,000$ & $>600$ & 863 & $>4550$ & 676 \\
\hline Oldest date & n/a & $3340-3000(\mathrm{~S})$ & n/a & $3210-2850(\mathrm{P})$ & $3060-2760(P)$ & $2715-2350(\mathrm{P})$ \\
\hline Form I bowl & $x$ & $x$ & $x$ & $x$ & $x$ & $x$ \\
\hline Form I flat-based bowl & $\mathrm{x}$ & $x$ & $x$ & $\mathrm{x}$ & $\mathrm{x}$ & - \\
\hline Form II & $(x)$ & $\mathrm{x}$ & - & $x$ & $x$ & - \\
\hline Form III & $x$ & $x$ & $x$ & $x$ & - & - \\
\hline Form IV & $x$ & $x$ & $x$ & $x$ & - & - \\
\hline Form V & $x$ & $\mathrm{x}$ & $\mathrm{x}$ & $x$ & $(\mathrm{x})$ & - \\
\hline Form VI & $x$ & $x$ & $x$ & $x$ & - & $x$ \\
\hline Form VII & $(x)$ & $x$ & $(x)$ & $x$ & $x$ & $x$ \\
\hline Form VIIIA stand & - & - & $x$ & - & - & - \\
\hline Form VIIIB stand & $x$ & $x$ & $x$ & - & $x$ & - \\
\hline Bowl-on-stand & $x$ & - & $x$ & - & - & - \\
\hline Cylinder stand & - & $x$ & $\mathrm{x}$ & - & - & - \\
\hline Notched lip & $x$ & $x$ & $x$ & $x$ & $x$ & $x$ \\
\hline Scalloped lip & $x$ & $x$ & $x$ & $x$ & $x$ & $x$ \\
\hline Dentate-stamped & $x$ & $x$ & $x$ & $x$ & $x$ & $x$ \\
\hline Incised/plain stamped & $x$ & $x$ & $x$ & $x$ & $x$ & $x$ \\
\hline Circle impressed & $x$ & $x$ & $x$ & $x$ & $x$ & $x$ \\
\hline Excised triangles & $x$ & $x$ & $x$ & - & - & - \\
\hline Cut-outs & - & - & $x$ & - & - & - \\
\hline Fingernail impressed & $x$ & - & - & $x$ & $x$ & $x$ \\
\hline Shell impressed & - & - & - & - & $x$ & $x$ \\
\hline Punctation & - & - & $x$ & - & $x$ & $x$ \\
\hline Applied relief & - & $x$ & $x$ & - & $x$ & $x$ \\
\hline Modelled heads & - & - & $x$ & - & - & - \\
\hline Face motifs & $x$ & $x$ & $x$ & - & - & - \\
\hline$N=25$ & $16(18)$ & 18 & $21(22)$ & 14 & $14(15)$ & 12 \\
\hline
\end{tabular}


isthmus sites, the exception being sherd FAAH/102 (Figure 11G). Alternatively, activity at the two areas could be essentially of the same age but reflecting different kinds of activities, as the oldest isthmus dates for pottery at FADC (Wk-12845: 3240-2960 cal. BP) and FAAH (Wk-10463 (3210-2850 cal. BP) overlap substantially with Beta-72144 (3390-3080 cal. BP) for FYS.

In terms of the presence or absence of certain stylistic attributes, Table 5 shows that the FAAH site is closer to the early Talasea area sites of FEA and FCR/FCS than it is to the younger FAO and FSZ sites, as would be expected from the date for FAAH/XVII. The FAAH collection shares all 14 of its pottery attributes with FEA and FCR/FCS, but only 11 with the younger sites. At this stage FAAH and the isthmus sites in general lack several early forms (e.g., pot stands, bowl-on-stand and thick channelled rims), several decorative techniques (e.g., cut-outs, excised triangles) and design elements (e.g., faces and curvilinear forms in general) that characterise early Lapita contexts in the Talasea area. The undated FACZ sherds could be as old as FAAH / XVII as they share with the earliest Talasea area groups of straight dentate-stamped lines with the ends closed by small plain arc impressions (cf. also the Arawe Islands: Summerhayes 2000).

The red surface treatments on the isthmus sherds match the values recorded for sherds in the Talasea area and in the Mussau Islands (Kirch 2001b:85; Specht and Torrence in press;). The technique of carving the sherd surface to form bas-relief at FAAH is currently not represented in the Talasea area, but is present in the Arawe Islands (Summerhayes 2000: Figs 5.31, 5.32), Duke of York Islands (White in press), on Ambitle Island off SE New Ireland (White and Specht 1971:Fig. 3), and on Eloaua Island in the Mussau group, where it occurs with broad grooved incision (e.g., Kirch 1997: Plate 5.1). The notched rim with an unusual surface colour at FACQ (Figure 10F) is similar to undated sherds on Garua Island that are also very thin and hard, though with dark grey surfaces (Specht and Torrence in press).

The isthmus assemblages have only one fingernail-impressed sherd. This sherd from FAAH has parallels on Garua Island (Specht and Torrence in press: Figs 5r, 5s), where the oldest fingernail impressions are dated to 2715-2350 cal. BP (NZA-3729) at FAO, somewhat later than the FAAH example (Specht and Torrence in press:Table 5). The isthmus lacks several decorative techniques that characterise the later pottery of the Talasea area, such as applied notched relief bands, applied angular knobs, punctate and shellimpressed designs. Sample bias is an obvious explanation, but as the techniques occur in the Talasea area in small samples comparable in size to those of the isthmus (Specht and Torrence in press:Tables 1, 2), this may not be the only reason. An alternative explanation may lie in their radiocarbon dates for the two areas. The six youngest isthmus dates bracket ca 2360 to 1900 cal. BP, well before the W-K3 event (1750-1550 cal. $\mathrm{BP}$ ), and only one of these came from an excavation level with pottery (Wk-12824, at FAAH/XLVI). The isthmus, then, might have been abandoned prior to the W-K3 event, whereas in the Garua Harbour area activity appears to have continued up to the $\mathrm{W}-\mathrm{K} 3$ event, but with changes in the pottery assemblages.

In summary, the ceramic analysis provides important information about the potential history of site use in the isthmus region. Based on stylistic criteria and comparisons with the Talasea area, the oldest pottery was probably deposited at FAAH and on Numundo Island. As at Talasea, there might have been a dichotomy between the coastal location of the small island of Numundo that was used for special purposes and mainland locations such as FAAH. On the other hand, the presence of what may be an early design element on the FACZ sherds, high on an inland foothill of Mt Krummel, and the early date (3240-2960 cal. BP) for plain pottery at FADC indicate that use of locations away from the coast occurred during an early phase of settlement in the isthmus region. This pattern contrasts with Garua Island, where the earliest dates come from a coastal location (FYS). Since we are monitoring human activities across a wide range of mainland environments rather than on a small island, the different pattern is perhaps not surprising. We can now incorporate the ceramic analyses into a broader discussion of land-use within the isthmus region. 


\section{Rapid re-colonisation}

Not surprisingly, the isthmus region was abandoned following the W-K2 volcanic disaster around 3480-3200 cal. BP. The depth of tephra deposited would have totally devastated settlements, cultivated plots, forests and reefs (Torrence and Doelman in press). Combined with the massive erosion and re-deposition that followed the eruption, the lack of resources would have made the area uninhabitable for some time (Torrence 2002b; Torrence and Doelman in press). Just how long the area was unoccupied is uncertain, but the dates show that the region was re-colonised by 3240-2960 cal. BP. These people introduced the knowledge of how to make and use pottery. But were they descendants of those who had previously lived in the area, or did they represent a new population? One way to approach this question is to examine the timing and nature of how the region was re-colonised.

Ceramic analysis has provided important indications that some sites in the isthmus region are likely to be as early as those in the Talasea area and therefore to be contemporary with the earliest recolonisation of Willaumez Peninsula. This conclusion is supported by the radiocarbon results from the isthmus test pits with pottery, which suggest that the appearance of pottery there was at the same time as or shortly after its appearance in the Talasea area.

Six of the 17 radiocarbon dates (Table 3 ) relate to pottery found in excavated contexts, two come from excavated levels without pottery but above sherds in lower levels, four are from test pits where pottery was found only in surface contexts, and five are from localities without any pottery. The oldest dates in each group in Table 3 are the same across the groups. This absence of difference suggests that pottery was present from the start of the re-colonisation phase; there was not an aceramic re-colonisation phase prior to the introduction of pottery.

The dates fall into two chronological groups: an older one of six dates where the age ranges exceed 3200-3000 years, and a younger one where they do not exceed 2760 years. This apparent pattern might be a function of the small number of dates, but could also indicate two phases of human activity in the region. Localities with pottery and those without are represented in each period. Secondly, the dates from different physiographic zones and elevations in the older group are similar to each other. The six oldest dates come from a range of elevations up to 40-80 $\mathrm{m}$ above sea level and up to $17-18 \mathrm{~km}$ from the current coastline.

We interpret this pattern as indicating that from the earliest arrival of people after $\mathrm{W}-\mathrm{K} 2$ and until the W-K3 event, all areas of the landscape were used for a wide range of activities, some of which included the use of ceramics. Since aceramic and ceramic localities are contemporary, there is no evidence to support the hypothesis that pottery was introduced from outside to people already in residence. Both types of sites occur in all landscape zones and are not segregated into different parts of the region. The most parsimonious interpretation of the data is that the same people created the artefact scatters at the ceramic and aceramic sites in the course of the many different kinds of activities that were necessary to sustain their livelihood. Pottery was probably used in only a small number of activities. Groups are unlikely to have always carried fragile pottery vessels wherever they went, particularly while engaged in hunting or foraging for bush foods and other useful products.

The widespread distribution of early dates shows that unlike on Garua Island, people moved into the inland zones of the isthmus very rapidly after the appearance of pottery in the Talasea area, possibly spreading inland from both east and west coasts. The speed of the re-colonisation suggests a number of possible models of behaviour. Firstly, people may have returned to places that were known to them because they were used prior to W-K2. The finding of three stemmed tools at FABN may indicate that this area was a particularly important place (Torrence 2004a), and there are dense scatters of obsidian 
artefacts and fire-cracked stone at locations on the spurs of the inland foothills, such as FACR and FACQ, suggesting repeated and / or heavy use of these locations prior to W-K2. Although the infilling of the tidal basin markedly changed the availability of local resources, these elevated positions would have been ideal for settlement and within range of the prime resources of the newly created river valley and swamp.

This point relates to a second possible explanation. The rapid movement of people into elevated settings both on the coast and inland may relate to landscape change following the W-K2 event. At the time when Lapita pottery was introduced, the low-lying areas on each side of the isthmus divide were swampy, locally saline and unsuitable for cultivation. Consequently, the selection of elevated locations on hills and ridges would have been a more practical and appropriate solution than the construction of stilt-houses over water or in swamps. Elevated situations such as the floodplain foothills of FADC, FACQ and FACR or the coastal hill of FAAH would have been more attractive locales for domestic activities.

Thirdly, the rapid spread of people could represent an extensive use of landscape based on the intensive use of wild resources, and/or cultivation with short fallow periods. Palaeo-environmental studies on the isthmus indicate widespread vegetation disturbance during the pottery period and this was probably associated with gardening (Boyd et al. 2005), but much more research is necessary to determine the precise system of cultivation.

A final possibility is that the region was heavily utilised from an early stage of re-colonisation, as the founding population was so large that people were forced to disperse quickly into the hinterland. An influx of people returning to a familiar environment following a natural disaster could certainly have created the observed pattern.

\section{Activity differentiation}

Following initial re-colonisation, activities were probably focused in particular locations, with others used less intensively or for specialised functions. The density of sherds at FAAH (especially in test pit XVII) suggests the use of the area as a settlement on a permanent or recurrent basis. In contrast, the smaller quantity of sherds recovered at the inland locations could indicate that the nature of activities expressed by the presence of pottery differed from those at FAAH. It is important to note that sherds did not occur in substantial numbers at the inland locations; Table 2 lists all sherds visible on the ground surface. In addition, a serious effort was made to test as many ridges as possible in the area where pottery had been exposed by road construction. The small areas available for settlement on these narrow, steep-sided ridges may have been as significant as their inland location near the swamps of the Kulu River floodplain. These small ridge locations could represent residential hamlets that were only occupied for a short time, whereas FAAH was a more permanent settlement or a focal point for some sort of special purpose activities, such as particular ceremonies, that involved the discard of relatively large amounts of pottery.

Several other places could have been used for special activities in which pottery played a role. During the early period of pottery use Numundo Island might have been used for activities that required a degree of isolation and / or proximity to the sea, as has been suggested for Boduna Island (site FEA) in the Talasea area (Specht and Summerhayes in press) and for other small islands (Specht this volume). The presence of dentate-stamped sherds that probably came from a single pot in the spring at FACZ could signify another type of special activity involving a relationship between water and pottery, although whether this was for ritual purposes or simply for collecting water for domestic consumption is open to speculation.

The remainder of the places where small samples of sherds were found are harder to interpret because they do not fit the typical model of a Lapita pottery village. At these locations only small amounts of 
pottery were used either because of the restricted nature of activities that took place, a low rate of breakage (and, by implication, the nature of ceramic use), or short-term occupation perhaps associated with the preparation and maintenance of cultivation plots. If these were settlements, then the limited quantities raise questions about the place and / or nature of pottery manufacture in daily life. Combining the small scatters into a single use category may be misleading, however, since they occur in a range of settings, including the seemingly different environments of inland and coastal hills and the strategic position of the divide between the eastern coastal plain and the Kulu floodplain. The widespread distribution of these locations with small amounts of pottery, as well as those with only obsidian artefacts, demonstrates that there is still much to learn about land-use practices during this period. Clearly both new methodologies and fresh perspectives are required to develop appropriate models for the cultural landscapes created by the users of Lapita pottery.

The overall picture obtained from the distribution of ceramics across the isthmus region is of an extensive system of land-use with a spatially differentiated pattern of various activities. The use of ceramics was not confined to permanent settlements. Finding out exactly how long places were utilised and for what reasons are obviously difficult tasks that will require larger excavations combined with rigorous analyses of the ceramic and non-ceramic assemblages. What is most important at this stage of research, however, is the range of new questions about land-use raised by the results of landscape archaeology in the isthmus region.

\section{Conclusions}

The adoption of a landscape perspective has enabled archaeology on Willaumez Peninsula to capitalise on the secure tephra sequence of the region and the increased access to inland zones made possible by plantation development. The results constitute a strong confirmation of the land-use strategies identified on Garua Island during the dentate-stamped phase of Lapita pottery, although the isthmus dates suggest that the inland component was established on the mainland earlier than on the offshore island. Just how long after the arrival of the pottery-makers the extensive land-use strategy was developed or whether an old pattern was re-established by the colonisers remains to be determined, but the available dates indicate that it could have occurred within a generation or two of arrival. Further survey and excavation work is clearly needed to address this issue and to determine the nature of the activities at the different kinds of locations, including off-shore islands (especially Numundo Island), high density ceramic discard at coastal settings (FAAH), small scatters on the coast (FAAY, FABO), inland (FACQ, FACR) and divide (FABH, FACU), and perhaps specialpurpose cache-like contexts (FACZ).

The common presence of dentate-stamped Lapita pottery in the Garua Harbour area might reflect a location strategy designed to facilitate - and perhaps monopolise - exploitation of the Kutau obsidian source, the products of which dominate early Lapita obsidian assemblages in Near Oceania and the SE Solomon Islands (Green 1987; Sheppard 1993; Specht 2002; Summerhayes 2004) as well as the isthmus itself (Torrence 2004b). No such explanation can be applied to the isthmus area. The number of dentate-stamped pottery sites currently on record in this area is much fewer than around Garua Harbour, but localities with pottery occur on both sides of the divide and some, on the eastern side at least, have direct access to the sea. Perhaps they formed part of a network of nodes for the distribution of obsidian and other products of the Peninsula, with the 'western' sites servicing Lapita settlements on the Kove and Siassi Islands (Lilley 1991, 2002, 2004), and the 'eastern' sites supplying areas such as Watom Island (Green and Anson 2000), the Duke of York Islands (White and Harris 1997) and locations further to the east and south. 
The apparent gap between the youngest W-K2 soil dates on the isthmus and those in the Garua Harbour area suggests the possibility that the isthmus was abandoned before the W-K3 event. As is evident in the range of dates on Table 3, an effort was made to test the apparent difference between the two areas by dating aceramic levels stratified directly under the $\mathrm{W}-\mathrm{K} 3$ tephra. The seeming abandonment might explain the absence from the isthmus of certain pottery traits that characterise the later pottery of Garua Harbour. The proposal by Torrence and Stevenson (2000:339-339) that the archaeological expression of shifting cultivation combined with relatively low population densities can simulate patterns of abandonment at small spatial scales might be appropriate here, but further research is clearly needed to find an explanation why there is a significant temporal break in the discard of cultural material in the isthmus region before the $\mathrm{W}-\mathrm{K} 3$ event.

The changing use of landscape on Willaumez Peninsula has profound implications for the interpretation of Lapita archaeology in other areas of its distribution. The oldest isthmus dates fall into the 'formative' period of the Lapita cultural complex in the Bismarck Archipelago (Specht this volume), arguably just before its dispersal southwards into Remote Oceania at about 3200-3000 years ago (Bedford 2003; Galipaud and Swete Kelly this volume; Pineda and Galipaud 1998; cf. Green 2003). The presence of early dates at elevated inland locations and the putatively early-stage dentate-stamped sherds at FACZ demonstrate that Lapita pottery-users on New Britain were already adept at exploiting non-marine zones by the time the cultural complex was carried southwards. These early Lapita communities were not tethered to coastal resources, but where opportunity allowed, they exploited inland resource zones. This has implications for modelling survival strategies and mobility potential within Near Oceania south of the Bismarck Archipelago and in at least some archipelagos of large islands in western Remote Oceania, such as Vanuatu and New Caledonia (cf. Anderson 2001).

In conclusion, the isthmus research has confirmed the inland component of land-use indicated by the Garua Island and FRI sites. It has revealed variations in land-use on Willaumez Peninsula that open new sets of questions and issues that will require new conceptual approaches and methods, as well as more intensive analyses of this rich new data set. More broadly, the results reinforce the view that Pacific archaeology would benefit from the extension of research throughout the Lapita pottery distribution into a wider range of environmental zones, including the inland sectors of islands (Anderson et al. 2000:315; Torrence and Stevenson 2000).

\section{Acknowledgments}

We acknowledge with appreciation funding and support provided by the Australian Research Council, Australia and Pacific Foundation, Pacific Biological Foundation, Australian Museum, Australian Institute of Nuclear Science and Engineering, and New Britain Palm Oil Ltd. We thank the following organisations for research permits, logistical and other support: National Research Institute (PNG); National Museum and Art Gallery (PNG); University of Papua New Guinea; West New Britain Provincial Cultural Centre; Mahonia Na Dari Research Station; Walindi Plantation Resort; Kimbe Bay Shipping Agencies, and especially the staff and management of New Britain Palm Oil Ltd. The isthmus project would have been impossible without the dedicated efforts of many volunteers whose hard work is much appreciated. We also thank Peter White for elevations of test pits; Richelle Spry for assistance with the ceramic analysis; Trudy Doelman for GIS analysis; Ghada Daher for pottery drawings; Fiona Roberts for the maps and figure lay-outs; and Cameron Petrie for radiocarbon age calibrations. 


\section{Endnote}

1. Anderson et al. (2001: Table 1) list five sites on Garua Island (FRD, FAAQ) and Willaumez Peninsula (FRI, FABH and FABN) that are not on or close to present-day shorelines. FRD should be deleted, as this site has not produced dentatestamped pottery. The inland site of Vunailau (SAU) on Watom Island should be added (Specht 1968:120). The only other inland sites listed are Vaturekuka (Parke 2000) and Qara-I-Oso II (Anderson et al. 2000) in Fiji. Since the gazetteer was published, another inland dentate-stamped pottery site has been reported from Fiji (Kumar 2002; Kumar and Nunn 2003). Two of these Fijian sites were recorded during non-archaeological field studies.

\section{References}

Anderson, A. 2001. Mobility models of Lapita migration. In G.R. Clark, A.J. Anderson and T. Vunidilo (eds), The Archaeology of Lapita Dispersal in Oceania, pp. 15-23. Canberra: Pandanus Books, Australian National University. Terra Australis 17.

Anderson, A., G. Clark and T. Worthy 2000. An inland Lapita site in Fiji. Journal of the Polynesian Society 109: 311-316.

Anderson, A., S. Bedford, G. Clark, I. Lilley, C. Sand, G. Summerhayes and R. Torrence 2001. An inventory of Lapita sites containing dentate-stamped pottery. In G.R. Clark, A.J. Anderson and T. Vunidilo (eds), The Archaeology of Lapita Dispersal in Oceania, pp. 1-13. Canberra: Pandanus Books, Australian National University. Terra Australis 17.

Bedford, S. 2003. The timing and nature of Lapita colonisation in Vanuatu: the haze begins to clear. In C. Sand (ed.), Pacific Archaeology: Assessments and prospects, pp. 147-158. Noumea: Département d'Archéologie, Service des Musées et du Patrimoine de Nouvelle-Calédonie. Les Cahiers de l'Archéologie en NouvelleCalédonie 15.

Bedford, S. 2006. The Pacific's earliest painted pottery: an added layer of intrigue to the Lapita debate and beyond. Antiquity 80: 544-557.

Best, S. 2002. Lapita: A View from the East. Auckland: New Zealand Archaeological Association. Monograph 24.

Boyd, W.E., C.J. Lentfer and J. Parr 2005. Interactions between human activity, volcanic eruptions and vegetation during the Holocene at Garua and Numundo, West New Britain. Quaternary Research 64: 384-398.

Felgate, M.W. 2003. Reading Lapita in Near Oceania: Intertidal and shallow-water pottery scatters, Roviana Lagoon, New Georgia, Solomon Islands. Unpublished PhD thesis, University of Auckland.

Frimigacci, D. 1980. Localisation éco-géographique et utilisation de l'espace de quelques sites Lapita de NouvelleCalédonie. Journal de la Société des Océanistes 66-67 (36): 5-11.

Gosden, C. and J. Webb 1994. The creation of a Papua New Guinean landscape: Archaeological and geomorphological evidence. Journal of Field Archaeology 21(1): 29-51.

Green, R. C. 1987. Obsidian results from the Lapita sites of the Reef/Santa Cruz Islands. In W.R. Ambrose and J.M.J. Mummery (eds), Archaeometry: Further Australasian Studies, pp.239-249. Canberra: Australian National University.

Green, R.C. 1992. Definitions of the Lapita Cultural Complex and its non-ceramic component. In J-C. Galipaud (ed.), Poterie Lapita et Peuplement, pp. 7-20. Noumea: ORSTOM.

Green, R.C. 2003. The Lapita horizon and traditions - signature for one set of Oceanic migrations. In C. Sand (ed.), Pacific Archaeology: Assessments and prospects, pp. 95-120. Noumea: Département d'Archéologie, Service des Musées et du Patrimoine de Nouvelle-Calédonie. Les Cahiers de l'Archéologie en Nouvelle-Calédonie 15.

Green, R.C. and D. Anson 2000. Excavations at Kainapirina (SAC), Watom Island, Papua New Guinea. New Zealand Journal of Archaeology 20 (1998): 29-94. 
Johnson, R.W. and D.H. Blake 1972. The Cape Hoskins area, southern Willaumez Peninsula, the Witu Islands, and associated volcanic centres, New Britain: volcanic geology and petrology. Canberra: Bureau of Mineral Resources, Geology and Geophysics. Record 1972/133.

Kirch, P.V. 1988. The Talepakemalai Lapita Site and Oceanic Prehistory. National Geographic Research 4(3): 328-342.

Kirch, P.V. 1997. The Lapita Peoples: Ancestors of the Oceanic World. Oxford: Blackwell.

Kirch, P.V. 2001a. A radiocarbon chronology for the Mussau Islands. In P.V. Kirch (ed.), Lapita and its Transformations in Near Oceania, pp. 196-222. Berkeley: Archaeological Research Facility, University of California at Berkeley. Contribution 59.

Kirch, P.V. 2001b. Three Lapita villages: Excavations at Talepakemalai (ECA), Etakosarai (ECB), and Etapakengaroasa (EHB), Eloaua and Emananus Islands. In P.V. Kirch (ed.), Lapita and its Transformations in Near Oceania, pp. 68-145. Berkeley: Archaeological Research Facility, University of California at Berkeley. Contribution 59.

Kumar, R. 2002. Discovery of a Lapita sherd inland of the Northeast coast of Viti Levu Island, Fiji: insights and implications. Suva: Institute of Applied Sciences, University of the South Pacific. IAS Technical Report 2002/5.

Kumar, R. and P.D. Nunn 2003. Inland and coastal Lapita settlement on Vitilevu Island, Fiji: New data. Domodomo 16(1): $15-20$

Lepofsky, D. 1988. The environmental context of Lapita settlement locations. In P.V. Kirch and T.L. Hunt (eds), Archaeology of the Lapita Cultural Complex: A critical review, pp. 33-47. Seattle: Thomas Burke Memorial Washington State Museum. Report 5.

Lilley, I. 1988. Type X: description and discussion of a prehistoric ceramic ware from northeastern Papua New Guinea. Bulletin of the Indo-Pacific Prehistory Association 8: 90-100.

Lilley, I. 1991. Lapita and post-Lapita developments in the Vitiaz Strait-West New Britain area. Bulletin of the IndoPacific Prehistory Association 11: 313-322.

Lilley, I. 2002. Lapita and Type Y in the KLK site, Siassi, Papua New Guinea. In S. Bedford, C. Sand and D. Burley (eds), Fifty Years in the Field. Essays in honour and celebration of Richard Shutler Jr's archaeological career, pp. 79-90. Auckland: New Zealand Archaeological Association. Monograph 25.

Lilley, I. 2004. Trade and culture history across the Vitiaz Strait, Papua New Guinea: the emerging post-Lapita coastal sequence. Records of the Australian Museum, Supplement 29: 89-96.

Lilley, I. and J. Specht in press. Revised dating of Type X pottery, Morobe Province, Papua New Guinea. Technical Reports of the Australian Museum.

Machida, H., R. Blong, J. Specht, H. Moriwaki, R. Torrence, Y. Hayakawa, B. Talai, D. Lolok and C.F. Pain 1996. Holocene explosive eruptions of Witori and Dakataua caldera volcanoes in West New Britain, Papua New Guinea. Quaternary International 34-36: 65-78.

McKee, C.O., H. Patia, J. Kuduon and R. Torrence 2005. Volcanic Hazard Assessment of the Krummel-Garbuna-Welcker Volcanic Complex, Southern Willaumez Peninsula, W.N.B., Papua New Guinea. Port Moresby: Geological Survey of Papua New Guinea. Report 2005/4.

Parke, A.L. 2000. Coastal and inland Lapita sites in Vanua Levu, Fiji. Archaeology in Oceania 35(3): 116-119.

Pavlides, C. 2006. Life before Lapita: new developments in Melanesia's long-term history. In I. Lilley (ed.), Archaeology of Oceania: Australia and the Pacific Islands, pp. 205-227. Oxford: Blackwell.

Petrie, C. and R. Torrence in prep. The chronology of eruption, abandonment and reoccupation, West New Britain c.7500 BC - AD 1880.

Pineda, R. and J-C. Galipaud 1998. Evidences archéologiques d'une surrection différentielle de l'île Malo (archipel du Vanuatu) au cours de l'Holocène récent. Comptes-rendus de l'Académie des Sciences de Paris. Sciences de la Terre et des Planètes 327: 777-779.

Ryburn, R. J. 1975. Talasea-Gasmata, New Britain. Sheet SB/56-5 \& SB/56-9. 1:250,000 Geological Series - Explanatory Notes. Canberra: Australian Government Publishing Service. 
Sheppard, P.J. 1993. Lapita lithics: trade/exchange and technology. A view from the Reefs/Santa Cruz. Archaeology in Oceania 28(3): 121-137.

Siorat, J.P. 1990. A technological analysis of Lapita pottery decoration. In M. Spriggs (ed.), Lapita Design, Form and Composition, pp. 59-82. Canberra: Department of Prehistory Australian National University. Occasional Papers in Prehistory 19.

Specht, J. 1968. Preliminary report of excavations on Watom Island. Journal of the Polynesian Society 77(2): 117-134. Specht, J. 2002. Obsidian, colonising and exchange. In S. Bedford, C. Sand and D. Burley (eds), Fifty Years in the Field. Essays in honour and celebration of Richard Shutler Jr's archaeological career, pp. 37-49. Auckland: New Zealand Archaeological Association. Monograph 25.

Specht, J., R. Fullagar and R. Torrence 1991. What was the significance of Lapita pottery at Talasea? Bulletin of the Indo-Pacific Prehistory Association 11: 281-294.

Specht, J. and R. Spry in prep. Pottery from the isthmus sites, Willaumez Peninsula, West New Britain, Papua New Guinea.

Specht, J. and G. Summerhayes in press. The Boduna Island (FEA) Lapita site, Papua New Guinea. Technical Reports of the Australian Museum.

Specht, J. and R. Torrence in prep. Pottery of the Talasea area, West New Britain Province, Papua New Guinea. Technical Reports of the Australian Museum.

Spriggs, M. 1984. The Lapita cultural complex: origins, distribution, contemporaries and successors. Journal of Pacific History 19(4): 202-223.

Spriggs, M. 1990. The changing face of Lapita: transformations of a design. In M. Spriggs (ed.), Lapita Design, Form and Composition, pp. 83-122. Canberra: Department of Prehistory, Australian National University. Occasional Papers in Prehistory 19.

Spriggs, M. 1997. The Island Melanesians. Blackwell: Oxford.

Summerhayes, G. 2000. Lapita Interaction. Canberra: Department of Archaeology and Natural History and Centre for Archaeological Research, Australian National University. Terra Australis 15.

Summerhayes, G. 2004. The nature of prehistoric obsidian importation to Anir and the development of a 3,000 year old regional picture of obsidian exchange within the Bismarck Archipelago, Papua New Guinea. Records of the Australian Museum, Supplement 29: 145-156.

Torrence, R. 2002a. Cultural landscapes on Garua Island, Papua New Guinea. Antiquity 76: 766-776.

Torrence, R. 2002b. What makes a disaster? Along-term view of volcanic eruptions and human responses in Papua New Guinea. In R. Torrence and J. Grattan (eds), Natural Disasters and Cultural Change, pp. 292-302. London: Routledge.

Torrence, R. 2004a. Pre-Lapita valuables in island Melanesia. Records of the Australian Museum, Supplement 29: 163-172. Torrence, R. 2004b. Now you see it. Now you don't. Changing obsidian source use in the Willaumez Peninsula, Papua New Guinea. In J. Cherry, C. Scarre and S. Shennan (eds), Explaining social change: studies in honour of Colin Renfrew, pp. 115-126. Cambridge: McDonald Institute for Archaeological Research.

Torrence, R. and T. Doelman in press. Chaos and selection in catastrophic environments. In J. Grattan and R. Torrence (eds), Living Under the Shadow: The Archaeological, Cultural and Environmental Impact of Volcanic Eruptions. Walnut Creek, California: Left Coast Press.

Torrence, R., C. Pavlides, P. Jackson and J. Webb 2000. Volcanic disasters and cultural discontinuities in Holocene time, in West New Britain, Papua New Guinea. In W.G. McGuire, D.R. Griffiths, P.L. Hancock and I.S. Stewart (eds), The Archaeology of Geological Catastrophes, pp. 225-244. London: The Geological Society of London. Special Publication 171.

Torrence, R., J. Specht and R. Fullagar 1990. Pompeiis in the Pacific. Australian Natural History 23(6): 456-463.

Torrence, R. and C.M. Stevenson 2000. Beyond the beach: changing Lapita landscapes on Garua Island, Papua New Guinea. In A. Anderson and T. Murray (eds), Australian Archaeologist: Collected Papers in Honour of Jim Allen, pp. 324-345. Canberra: Coombs Academic Publishing, Australian National University 
Torrence, R., V. Neall, T. Doelman, E. Rhodes, C. McKee, H. Davies, R. Bonetti, A. Guglielmetti, A. Manzoni, M. Oddone, J. Parr and C. Wallace 2004. Pleistocene colonisation of the Bismarck Archipelago: new evidence from West New Britain. Archaeology in Oceania 39(3): 101-130.

White, J.P. in press. Ceramic sites on the Duke of York Islands, Papua New Guinea. Technical Reports of the Australian Museum.

White, J.P., C. Coroneos, V. Neall, W. Boyd and R. Torrence 2002. FEA site, Boduna Island: further investigations. In S. Bedford, C. Sand and D. Burley (eds), Fifty Years in the Field. Essays in honour and celebration of Richard Shutler Jr's archaeological career, pp. 101-107. Auckland: New Zealand Archaeological Association. Monograph 25.

White, J.P. and M-N. Harris 1997. Changing sources: early Lapita period obsidian in the Bismarck Archipelago. Archaeology in Oceania 32(1): 97-107.

White, J.P. and J. Specht 1971. Prehistoric pottery from Ambitle Island, Bismarck Archipelago. Asian Perspectives 14: 88-94.

Wickler, S. 2001. The Prehistory of Buka: A Stepping Stone Island in the Northern Solomons. Canberra: Department of Archaeology and Natural History and Centre for Archaeological Research, Australian National University. Terra Australis 16. 